Prepared in cooperation with the Bureau of Land Management

\title{
Baseline Groundwater Hydrology and Water Quality In and Around Bluff, Utah
}

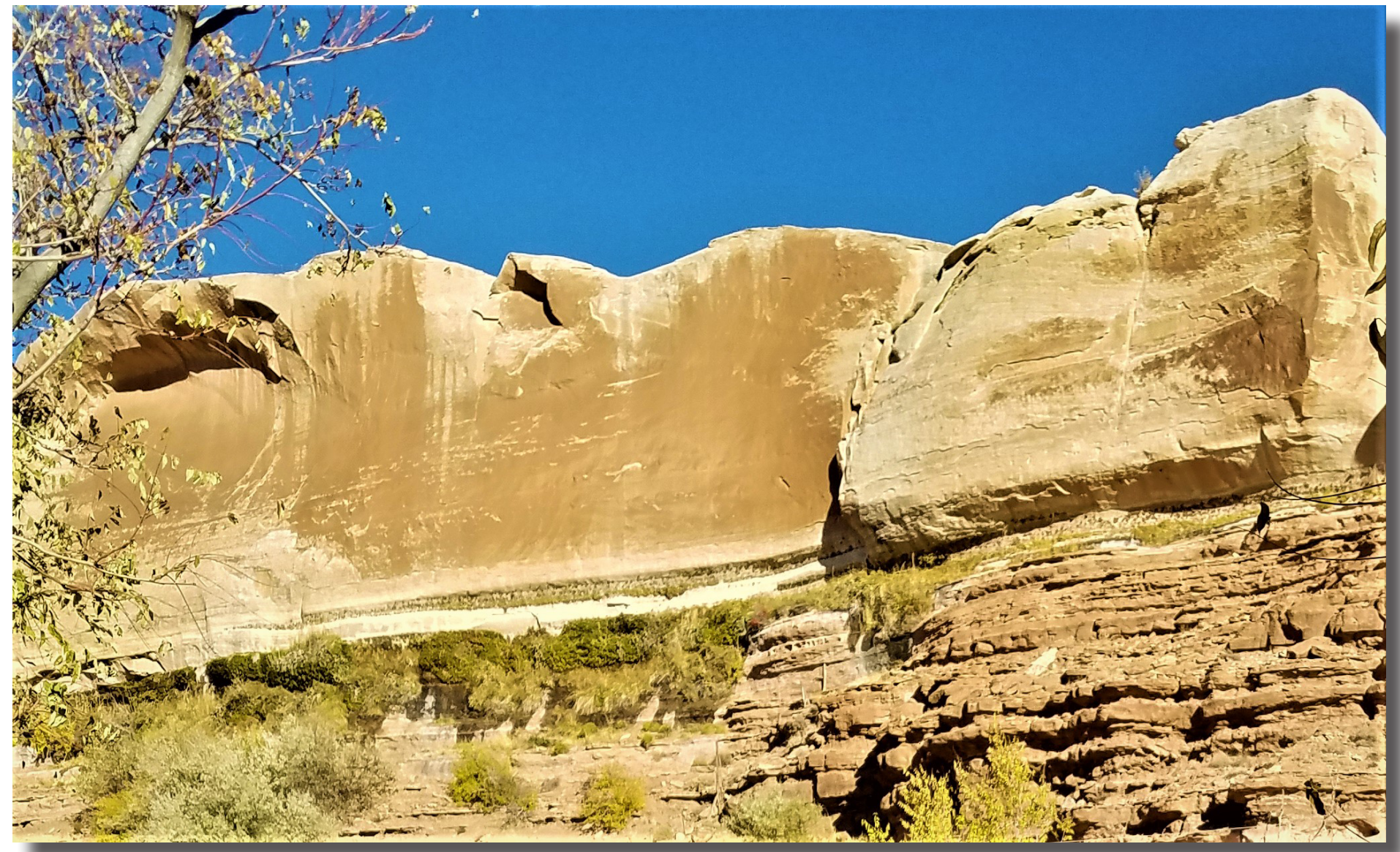

Open-File Report 2019-1076

U.S. Department of the Interior

U.S. Geological Survey 
Cover photo: View showing groundwater-fed hanging gardens east of Bluff, Utah. Bluff Sandstone overlies thin-bedded Summerville Formation. Photograph taken by Nora Nelson, U.S. Geological Survey, October 25, 2017. 


\section{Baseline Ground water Hydrology and Water Quality In and Around Bluff, Utah}

By Olivia L. Miller

Prepared in cooperation with the Bureau of Land Management

Open-File Report 2019-1076 


\title{
U.S. Department of the Interior DAVID BERNHARDT, Secretary
}

\author{
U.S. Geological Survey \\ James F. Reilly II, Director
}

U.S. Geological Survey, Reston, Virginia: 2019

For more information on the USGS - the Federal source for science about the Earth, its natural and living resources, natural hazards, and the environment-visit https://www.usgs.gov or call 1-888-ASK-USGS.

For an overview of USGS information products, including maps, imagery, and publications, visit https://store.usgs.gov.

Any use of trade, firm, or product names is for descriptive purposes only and does not imply endorsement by the U.S. Government.

Although this information product, for the most part, is in the public domain, it also may contain copyrighted materials as noted in the text. Permission to reproduce copyrighted items must be secured from the copyright owner.

Suggested citation:

Miller, O.L., 2019, Baseline groundwater hydrology and water quality in and around Bluff, Utah: U.S. Geological Survey Open-File Report 2019-1076, 24 p., https://doi.org/10.3133/ofr20191076. 


\section{Acknowledgments}

Funding for this study was provided by the Bureau of Land Management. Bluff Water Works and well owners are gratefully acknowledged for granting permission to sample their wells. 


\section{Contents}

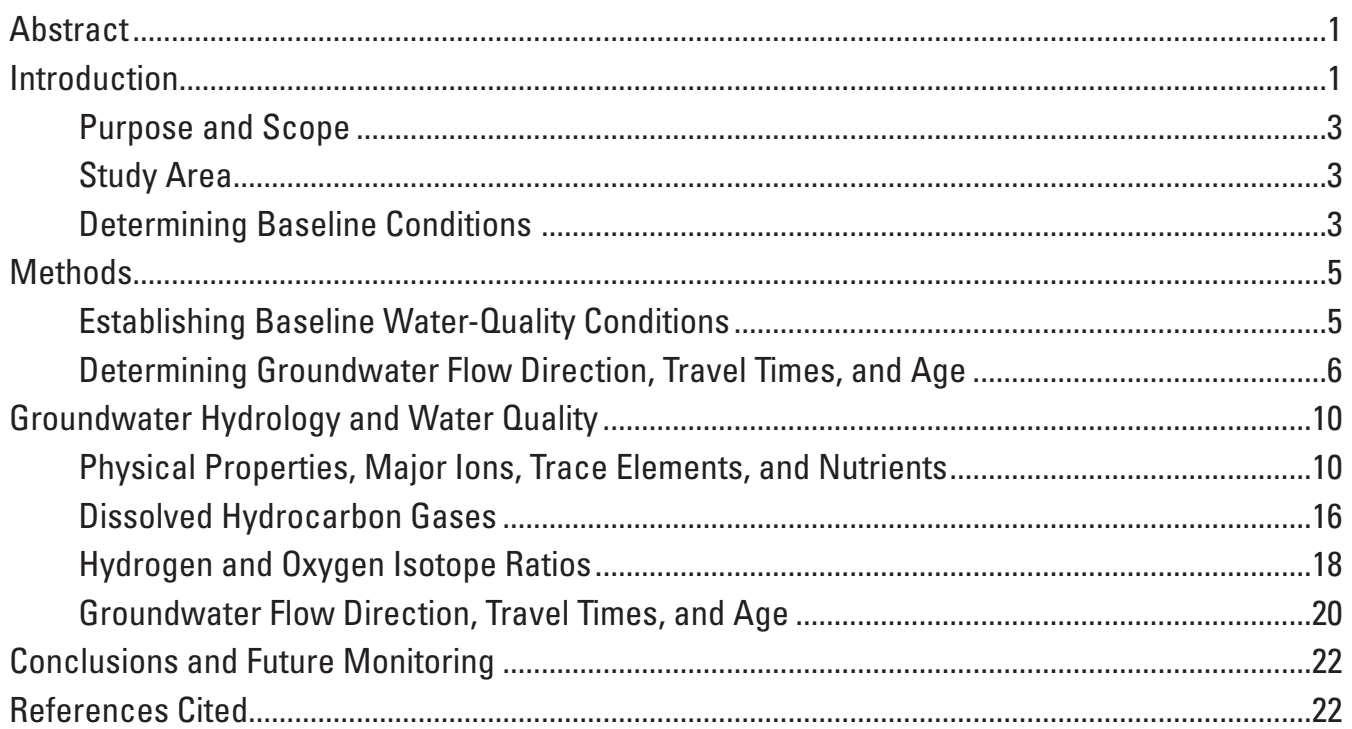

\section{Figures}

1. Map showing study area, existing oil and gas wells, proposed production wells, and water wells with water-level and water-quality data, in and around Bluff, Utah ......2

2. Diagram showing generalized stratigraphy and aquifer systems in the study area in and around Bluff, Utah.

3. Graphs showing physical properties and concentrations of major ions, and selected trace elements and nutrients in water samples collected in and around Bluff, Utah, for this study compared to pre-existing data....

4. Graphs showing statistical distribution of physical properties, major ions, and selected trace elements and nutrients in filtered and unfiltered water samples collected from wells, springs, and surface-water sites in and around Bluff, Utah.........14

5. Graphs showing bromide and chloride concentrations in water samples collected from the principal bedrock aquifers, San Juan River, and the adjacent alluvial aquifer in and around Bluff, Utah, between 1992 and 2017, compared to bromide and chloride concentrations in oil-field brines from the Aneth Oil Field.

6. Graphs showing the isotopic composition of groundwater and surface-water samples collected in and around Bluff, Utah, in relation to the global and Salt Lake Valley meteoric water lines and the isotopic composition of groundwater, surface-water, and precipitation samples, and oil-field brines in relation to the global and Salt Lake Valley meteoric water lines.

7. Map showing potentiometric surface contours from water-level measurements made between 2012 and 2017 at wells in and around Bluff, Utah. 


\section{Tables}

1. Locations of groundwater and surface-water sites in and around Bluff, Utah, and date range for which general chemistry, dissolved hydrocarbon gas, hydrogen and oxygen isotope ratio, and water-level data were compiled or collected..

2. Physical properties of water samples collected from selected wells in the principal bedrock aquifers and from the San Juan River in and around Bluff, Utah, December 4 to 7, 2017.

3. Concentrations of major ions, and selected trace elements and nutrients in water samples collected from selected wells in the principal bedrock aquifers and from the San Juan River in and around Bluff, Utah, December 4 to 7, 2017.

4. Summary statistics for selected chemical constituents for which drinking-water standards have been established from water samples collected in and around Bluff, Utah, compared to drinking-water standards

5. Composition of dissolved gases in water samples collected from selected wells in the principal bedrock aquifers and from the San Juan River in and around Bluff, Utah, December 4 to 7, 2017

6. Hydrogen and oxygen isotope ratios of water samples collected from selected wells in the principal bedrock aquifers and from the San Juan River in and around Bluff, Utah, December 4 to 7, 2017

\section{Conversion Factors}

U.S. customary units to International System of Units

\begin{tabular}{|c|c|c|}
\hline Multiply & By & To obtain \\
\hline \multicolumn{3}{|c|}{ Length } \\
\hline foot $(\mathrm{ft})$ & 0.3048 & meter $(\mathrm{m})$ \\
\hline mile (mi) & 1.609 & kilometer (km) \\
\hline \multicolumn{3}{|c|}{ Flow rate } \\
\hline foot per day (ft/d) & 0.3048 & meter per day $(\mathrm{m} / \mathrm{d})$ \\
\hline
\end{tabular}

Temperature in degrees Celsius $\left({ }^{\circ} \mathrm{C}\right)$ can be converted to degrees Fahrenheit $\left({ }^{\circ} \mathrm{F}\right)$ as follows:

$$
{ }^{\circ} \mathrm{F}=\left(1.8 \times{ }^{\circ} \mathrm{C}\right)+32 .
$$

Temperature in degrees Fahrenheit $\left({ }^{\circ} \mathrm{F}\right)$ can be converted to degrees Celsius $\left({ }^{\circ} \mathrm{C}\right)$ as follows:

$$
{ }^{\circ} \mathrm{C}=\left({ }^{\circ} \mathrm{F}-32\right) / 1.8 \text {. }
$$

\section{Datums}

Horizontal coordinate information is referenced to the North American Datum of 1983 (NAD 83).

Vertical coordinate information is referenced to the North American Vertical Datum of 1988 (NAVD 88).

Altitude, as used in this report, refers to distance above the vertical datum. 


\section{Supplemental Information}

Specific conductance is given in microsiemens per centimeter at 25 degrees Celsius $(\mu \mathrm{S} / \mathrm{cm}$ at $\left.25^{\circ} \mathrm{C}\right)$.

Concentrations of chemical constituents in water are given in either milligrams per liter (mg/L) or micrograms per liter ( $\mu \mathrm{g} / \mathrm{L})$.

Radiochemical concentrations are given in units of picocurie per liter (pCi/L).

\section{Abbreviations}

$\begin{array}{ll}{ }^{14} \mathrm{C} & \text { carbon-14 } \\ \mathrm{CO}_{2} & \text { carbon dioxide } \\ \delta^{13} \mathrm{C} & \text { delta carbon-13 } \\ \delta^{18} \mathrm{C} & \text { delta oxygen-18 } \\ \delta^{2} \mathrm{H} & \text { delta deuterium } \\ \mathrm{MCL} & \text { maximum contaminant level } \\ \text { NWIS } & \text { National Water Information System } \\ \text { pMC } & \text { percent modern carbon } \\ \text { SDWIS } & \text { Safe Drinking Water Information System } \\ \text { SMCL } & \text { secondary maximum contaminant level } \\ \text { USGS } & \text { U.S. Geological Survey }\end{array}$




\section{Well-Numbering System}

The system of numbering wells, springs, and other hydrologic-data sites in Utah is based on the cadastral land-survey system of the U.S. Government. The number, in addition to designating the site, describes its position in the land net. The land-survey system divides the State into four quadrants by the Salt Lake Meridian and Base Line. These quadrants are designated by the uppercase letters $A, B, C$, and $D$, indicating respectively, the northeast, northwest, southwest, and southeast quadrants. Numbers designating the township and range, in that order, follow the quadrant letter, and the three are enclosed in parentheses. The number after the parentheses indicates the section and is followed by three lowercase letters indicating the quarter section, the quarter-quarter section, and the quarter-quarter-quarter section, generally 10 acres for regular sections. The lowercase letters a, b, c, and d indicate, respectively, the northeast, northwest, southwest, and southeast quarters of each subdivision. The number after the letters is the serial number of the site within the 10 -acre tract. The letter $S$ preceding the serial number denotes a spring. Thus, (D-40-21)25acd-1 designates the first well constructed or cataloged in the southeast quarter of the southwest quarter of the northeast quarter of section 25, T. 40 S., R. 21 E.

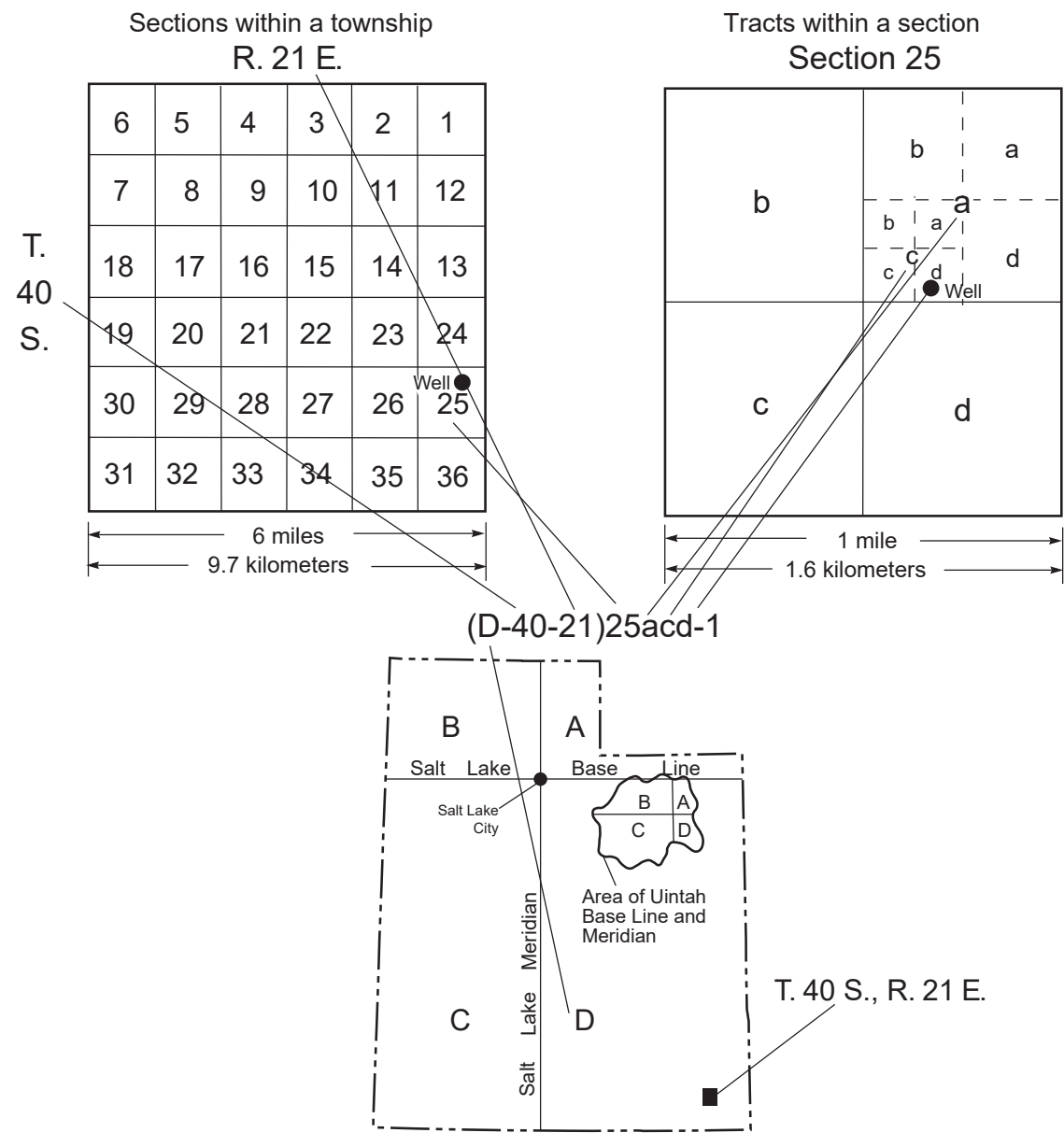




\title{
Baseline Groundwater Hydrology and Water Quality In and Around Bluff, Utah
}

\author{
By Olivia L. Miller
}

\section{Abstract}

Southeastern Utah has a long history of oil and gas production. Two new hydrocarbon extraction wells have been proposed several miles northeast of the town of Bluff, Utah. In response to concern about the impacts of oil and gas extraction in the area on drinking-water quality, this study provides groundwater quality and hydrologic baseline data obtained before drilling the new hydrocarbon extraction wells. Data from future monitoring can be compared to these baseline water-quality data to identify changes in water quality. The quality of drinking water in Bluff is generally good, making changes in water quality more easily identifiable. Potential degradation of water quality from the proposed production wells could take hundreds to thousands of years to reach public-supply wells. Because of the limited water supply in this area, high-quality groundwater will continue to be an important resource into the foreseeable future.

\section{Introduction}

The town of Bluff, Utah, primarily obtains its municipal water supply from wells completed in bedrock aquifers, including the Glen Canyon Group. The Glen Canyon Group includes the Entrada, Navajo, and Wingate aquifers. The region has a long history of oil and gas development centered on the Aneth Oil Field to the east of Bluff that began in the mid-1950s. New hydrocarbon production wells have been proposed 5 to 7 miles (mi) northeast of Bluff, east of highway 191 (fig. 1). These wells will be drilled through formations from which the town's municipal water supply is sourced and will be used for the injection of high-pressure fluids to hydraulically fracture deeper formations to enhance recovery. The new wells are expected to be completed at depths of 4,000 to 7,000 feet (ft). Residents of Bluff have expressed concern about future potential impacts on their municipal water supply from the proposed drilling activities and well operations.

Most groundwater degradation from oil and gas operations results from surface spills (Jackson and others, 2013). Surface spills or leaks can happen during storage, transportation, and handling of hydraulic fracturing fluids, produced water, oil-field brines, or extracted hydrocarbons. Another potential pathway for groundwater degradation related to hydrocarbon extraction is migration of fluids vertically along improperly constructed wells, compromised well casings, or geologic faults and fractures (natural or induced). The most common cause of stray gas migration is poor well construction (Gorody, 2012; Jackson and others, 2013). Contaminants can include hydraulic fracturing fluids, produced wastewater, and oil and gas.

Hydraulic fracturing fluids, which consist of water mixed with proppants and chemicals (for example, acids, viscosity adjusters, stabilizers, biocides, and surfactants), are injected into hydrocarbon reservoirs at high pressure to induce fracture formation to improve hydrocarbon recovery (Jackson and others, 2013). The composition of hydraulic fracturing fluids can vary; therefore, the fate, transport, and toxicity can vary. Few studies have evaluated the chemistry or assessed the health and environmental impacts of hydraulic fracturing fluids (Werner and others, 2015).

Produced water refers to any water from a hydrocarbon production well, including flowback water, formation brine, and water condensing from the gas phase (Orem and others, 2014). Produced water typically contains high concentrations of dissolved solids, primarily sodium and chloride, but also can include other potentially harmful constituents, such as arsenic. Depending on the constituent and its concentration, leakage of produced waters into aquifers can degrade water quality in the aquifer, resulting in a range of possible impacts from poor taste to human health effects.

Gas in groundwater can consist of free gas in pore space or dissolved gas. Methane is the primary component of natural gas. Although no water-quality standards establish limits for methane in drinking water, the U.S. Department of the Interior, Office of Surface Mining, states that methane concentrations in groundwater over 28 milligrams per liter $(\mathrm{mg} / \mathrm{L})$ indicate that potentially explosive or flammable quantities of methane are being released from groundwater and that ventilation is necessary (Eltschlager and others, 2001). Oxidation of methane in an aquifer is associated with changes in groundwater chemistry, particularly in confined aquifers (Vengosh and others, 2014; Roy and others, 2016). 


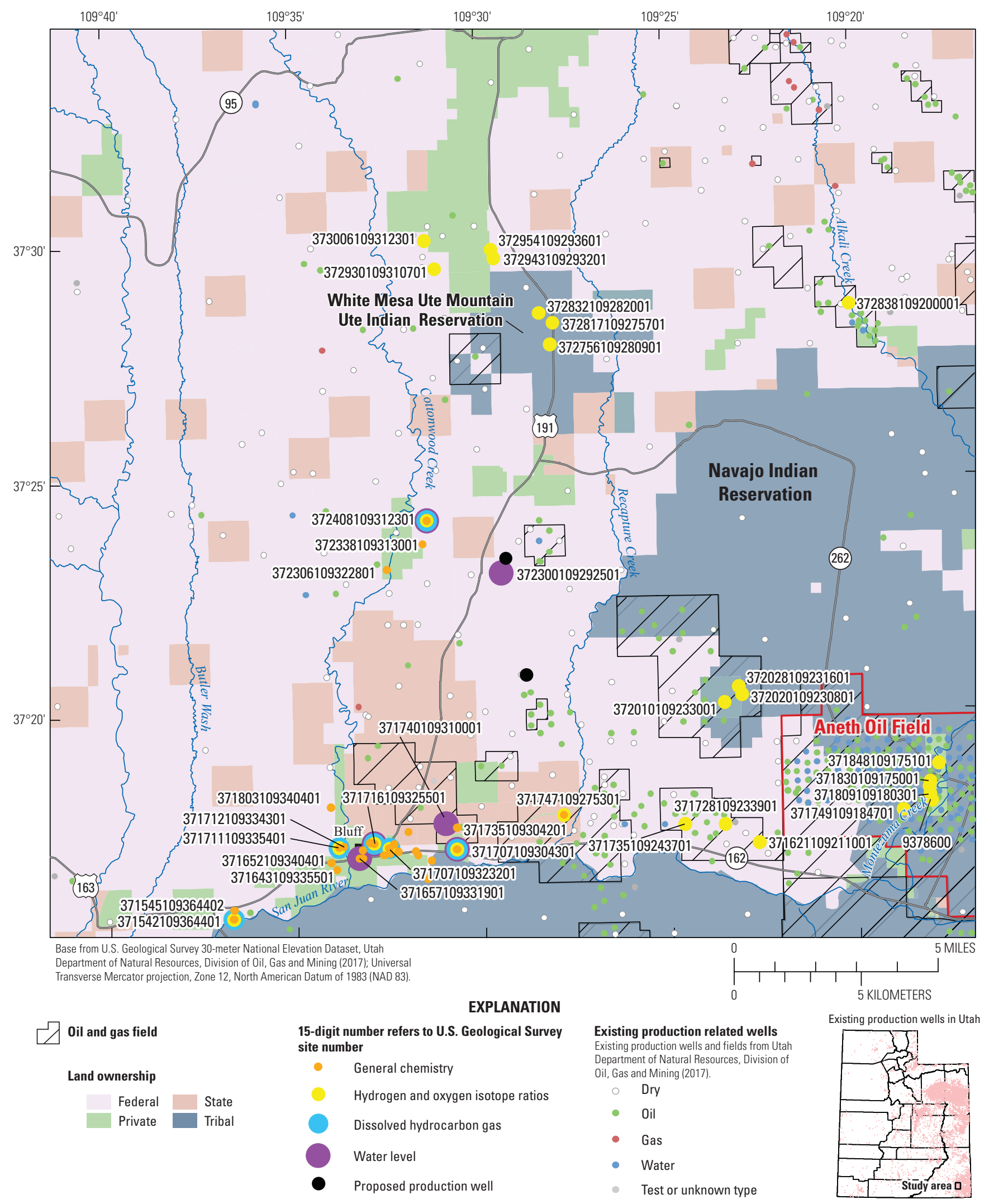

Figure 1. Study area, existing oil and gas wells, proposed production wells, and water wells with water-level and water-quality data, in and around Bluff, Utah. 
The proposed production wells represent one potential source of groundwater degradation in the study area (fig. 1). In this report, the term "production well" is used to refer to oil and gas wells. Production wells can potentially allow formation waters to migrate along poorly sealed casings or through the borehole into adjacent aquifers. Surface activity related to oil and gas production represents another potential source of groundwater degradation. Chemicals and produced water stored and transported on the land surface can leak and potentially infiltrate into aquifers.

\section{Purpose and Scope}

The Bureau of Land Management (BLM) requested that the U.S. Geological Survey (USGS) conduct a reconnaissance assessment of groundwater north of the San Juan River near Bluff, Utah, to provide data and information for the environmental compliance of several production wells proposed northeast of Bluff. The purpose of this report is to present baseline data on groundwater quality, water levels, and directions of groundwater movement for the area north of the San Juan River near Bluff, Utah. These baseline data, obtained before installation of the proposed production wells, can be used to assess potential changes in groundwater quality that could occur as a result of these activities.

The general approach for this assessment was to compile existing water-quality, water-level, and aquifer-property data and obtain several additional groundwater samples and waterlevel measurements to (1) establish baseline water-quality conditions and characterize potential contamination sources, (2) determine groundwater flow directions, (3) determine groundwater travel times, and (4) provide insights related to future monitoring.

\section{Study Area}

The study area is in southeastern Utah, near the town of Bluff, located along the San Juan River (fig. 1). The lithology of the area mostly consists of relatively flat-lying sedimentary rocks that are composed of interbedded sandstone, siltstone, shale, mudstone, and conglomerate (fig. 2). Volcanic intrusions into these sedimentary rocks form mountainous areas north of the study area, including the Abajo Mountains, west of Monticello. Streams dissect the sedimentary rocks, forming canyons, and flow generally south into the San Juan River.

Water-yielding formations in the region have been grouped into multiple aquifer systems consisting of a sequence of bedrock aquifers and confining units underlying local alluvial aquifers (fig. 2). The principal bedrock aquifers include the Dakota Sandstone (D aquifer), Morrison Formation (including the Bluff Sandstone) (M aquifer), and the Entrada, Navajo, and Wingate Sandstones (N aquifer) (Avery, 1986). Aquifers in the Bluff, Entrada, Navajo, and Wingate Sandstones are typically confined in the study area. The Bluff Sandstone is the primary water-bearing unit of the Morrison Formation. Groundwater in the shallower D, M, and
$\mathrm{N}$ aquifers is typically fresh outside of the Aneth Oil Field, whereas water in deeper formations underlying the Cedar Mesa Sandstone (P aquifer) is typically briny (Whitfield and others, 1983; Avery, 1986). The Paradox Formation is the primary hydrocarbon-producing reservoir in the region.

Recharge to the principal aquifers occurs through infiltration of precipitation, seepage from streams, subsurface flow, and interformational leakage. Recharge from infiltration of precipitation occurs where aquifer formations crop out and is enhanced near mountainous areas where higher rates of precipitation occur. Fractures associated with intrusion of volcanic rocks can enhance recharge. Discharge from the principal aquifers is to the San Juan River, larger perennial streams, springs and wells, and as subsurface and interformational flow. Springs and flowing wells completed in these formations indicate that the potentiometric surface is at or above the land surface.

\section{Determining Baseline Conditions}

Collecting baseline groundwater-quality data before installation of the two proposed production wells is part of a strategy to evaluate potential future impacts. Continued monitoring following production-well construction is also necessary to identify changes in water quality over time. Considering the multiple potential sources and pathways that could potentially impact Bluff's drinking-water supply, a range of chemical constituents were evaluated to enable detection of changes that can happen because of hydrocarbon extraction processes. New and existing water-quality data from in and around Bluff, Utah, were compiled for this study to establish baseline water-quality conditions for constituents that have been used to evaluate water-quality degradation from hydrocarbon extraction activities. These baseline data provide a reference to which future water-quality data can be compared to determine if water quality has changed over time.

Produced water and oil-field brines can potentially be identified by dissolved-solids concentrations, bromide and chloride concentrations, and stable hydrogen (deuterium) and oxygen-18 isotope ratios (Breen and others, 1985; Osborn and McIntosh, 2010; Warner and others, 2012). Produced water can contain high concentrations of dissolved solids, and increases in dissolved solids in drinking water can indicate potential mixing with produced water. In the Uinta Basin, Utah, bromide and chloride concentrations in water along with hydrogen and oxygen isotope ratios have been used as signatures of produced water (Steiger, 2007). Bromide, chloride, and hydrogen and oxygen isotope ratios also have been used to distinguish water from the Navajo aquifer and formation brines in and near the Aneth Oil Field (Naftz and Spangler, 1994). Spangler and others (1996) used bromideto-chloride ratios to show that the high salinity in the Navajo aquifer had geochemical signatures consistent with upward movement of saline water from the Upper Paleozoic aquifer or from local dissolution of evaporites in the Navajo aquifer, as opposed to mixing with oil-field brines. 


\begin{tabular}{|c|c|c|c|c|c|c|}
\hline Era & System & Formation & Member & General lithology & $\begin{array}{l}\text { Approximate } \\
\text { maximum } \\
\text { thickness } \\
\text { (feet) }\end{array}$ & Aquifer \\
\hline \multirow{2}{*}{ 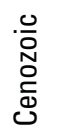 } & Quaternary & \multicolumn{2}{|l|}{ Alluvium } & $\mathrm{Si}, \mathrm{Sa}, \mathrm{G}$ & $0-100$ & Alluvial aquifer \\
\hline & Tertiary & \multicolumn{2}{|l|}{ Igneous intrusions } & $P$ & & \\
\hline \multirow{16}{*}{ 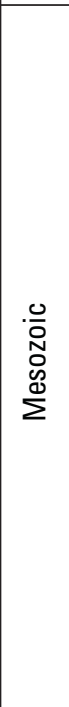 } & \multirow{3}{*}{ Cretaceous } & \multicolumn{2}{|l|}{ Mancos Shale } & $\mathrm{Sh}, \mathrm{M}, \mathrm{Si}$ & & Confining \\
\hline & & \multicolumn{2}{|l|}{ Dakota Sandstone } & $\mathrm{Sa}, \mathrm{Co}$ & 150 & \multirow{2}{*}{ D aquifer } \\
\hline & & \multicolumn{2}{|l|}{ Burro Canyon Formation } & $\mathrm{Sa}, \mathrm{Co}, \mathrm{Sh}$ & 160 & \\
\hline & \multirow{12}{*}{ Jurassic } & & Brushy Basin & M, Si & 700 & Confining \\
\hline & & \multirow{4}{*}{ Morris on Formation } & Westwater Canyon & f-c Sa & 180 & \multirow{4}{*}{ M aquifer } \\
\hline & & & Recapture & $f-m$ Sa & 200 & \\
\hline & & & Salt Wash & $f-m S a, S i, L$ & 400 & \\
\hline & & & Bluff Sandstone & $\mathrm{f}-\mathrm{m} \mathrm{Sa}$ & 300 & \\
\hline & & \multicolumn{2}{|c|}{ Summerville Formation } & Sh, M, Si & 200 & Confining \\
\hline & & \multicolumn{2}{|l|}{ Entrada Sandstone } & $\mathrm{Sa}$ & 550 & \multirow{5}{*}{$\mathrm{N}$ aquifer } \\
\hline & & \multicolumn{2}{|l|}{ Carmel Formation } & $\mathrm{Sh}, \mathrm{Si}, \mathrm{Sa}$ & 100 & \\
\hline & & \multicolumn{2}{|l|}{ Navajo Sandstone } & $f-m S a$ & 600 & \\
\hline & & \multicolumn{2}{|l|}{ Kayenta Formation } & $\mathrm{Sa}, \mathrm{Si}$ & Average 150 & \\
\hline & & \multicolumn{2}{|l|}{ Wingate Sandstone } & $\mathrm{Sa}$ & 650 & \\
\hline & & \multicolumn{2}{|l|}{ Chinle Formation } & $\mathrm{Si}, \mathrm{Sa}, \mathrm{Sh}, \mathrm{M}, \mathrm{Co}$ & 1,400 & \multirow{2}{*}{ Confining } \\
\hline & Triassic & \multicolumn{2}{|l|}{ Moenkopi Formation } & $\mathrm{Si}, \mathrm{Sa}$ & 350 & \\
\hline \multirow{9}{*}{ 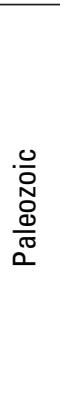 } & \multirow{5}{*}{ Permian } & \multirow{5}{*}{ Cutler Formation } & White Rim Sandstone & $\mathrm{m}-\mathrm{c} \mathrm{Sa}$ & & \\
\hline & & & De Chelly Sandstone & $\mathrm{fSa}$ & 400 & C aquifer \\
\hline & & & Organ Rock Tongue & $\mathrm{Si}, \mathrm{Sa}$ & 650 & \\
\hline & & & \begin{tabular}{|l} 
Cedar Mesa Sandstone \\
\end{tabular} & f-c Sa, E, Si, Sh & 1,200 & $\mathrm{P}$ aquifer \\
\hline & & & Halgaito Tongue & Sh, Si, vf Sa & 480 & \multirow{5}{*}{ Brine } \\
\hline & \multirow{4}{*}{ Pennsylvanian } & \multicolumn{2}{|l|}{ Rico Formation } & $\mathrm{L}, \mathrm{f}-\mathrm{m} \mathrm{Sa}, \mathrm{Si}$ & 300 & \\
\hline & & \multirow{3}{*}{ Hermosa Formation } & Honaker Trail & L, Sa, Si, Co & 1,800 & \\
\hline & & & Paradox main oil-bearing unit & $\mathrm{Si}, \mathrm{Sh}, \mathrm{Sa}, \mathrm{L}, \mathrm{E}$ & 11,000 & \\
\hline & & & Pinkerton Trail & L, Sh & 300 & \\
\hline
\end{tabular}

EXPLANATION

$\begin{array}{llll}\text { Principal bedrock aquifer } & \text { General lithology grain size (lower case) } & \text { General lithology rock type (upper case) } \\ \text { Brine } & \mathrm{Sf}=\text { very fine } & \mathrm{Sa}=\text { sandstone } & \mathrm{C} \text { = mudstone } \\ & \mathrm{f}=\text { fine } & \mathrm{G}=\text { gravel } & \mathrm{L}=\text { limestonerate } \\ \mathrm{m}=\text { medium } & \mathrm{Sh}=\text { shale } & E=\text { evaporite } \\ \mathrm{C}=\text { coarse } & & \mathrm{P}=\text { porphyritic }\end{array}$

Figure 2. Generalized stratigraphy and aquifer systems in the study area in and around Bluff, Utah.

Methane, carbon and hydrogen isotopes, and other organic compounds such as ethane and propane also have been used to characterize produced waters, distinguish between gas sources in shallow aquifers, and determine formation processes (Osborn and McIntosh, 2010; Orem and others, 2014; Humez and others, 2016). Isotope ratios can be reported as delta $(\delta)$ values, which are parts per thousand or permil (\%o) difference(s) from a standard. Isotope ratios of carbon-13 and hydrogen in methane can be used to distinguish between biogenic gases produced in situ and thermogenic gases produced at higher pressures and temperatures. Biogenic methane $\delta^{13} \mathrm{C}$ values range from -50 to -110 permil, whereas thermogenic methane $\delta^{13} \mathrm{C}$ values typically range from -25 to -55 permil (Jackson and others, 2013). The gas composition of different sources varies as well. Biogenic natural gas mainly contains methane whereas thermogenic gas often contains ethane and propane, in addition to methane (Jackson and others, 2013). 


\section{Methods}

Before this study, a limited number of water samples collected from the study area had been analyzed for tracers typically used to identify water-quality degradation from hydrocarbon production. For this study, samples were collected from five wells and one site on the San Juan River in December 2017 and analyzed for general chemistry (including bromide and chloride concentrations), stable oxygen-18 and hydrogen (deuterium) isotope ratios, and methane (and carbon-13 and hydrogen isotope ratios of methane), propane, and ethane concentrations.

Understanding the direction of groundwater flow can be used to help determine contaminant movement through an aquifer. Vertical hydraulic gradients also can be used to evaluate susceptibility of an aquifer to degradation. Avery (1986) developed an initial potentiometric surface map of several bedrock aquifers in San Juan County in 1986. Groundwater conditions and flow systems, however, can change substantially over 30 years as the regional population and associated groundwater development increases. Although the area around Bluff has less groundwater development than other parts of Utah, with withdrawals less than 20,000 acrefeet per year (Burden and others, 2016), a reassessment of the potentiometric surface is still useful in conjunction with the baseline water-quality assessment. In addition, many wells in the study area only have one or two water-level measurements. Water-level measurements made since 2012, and for this study, were compiled to develop a new potentiometric surface map showing general directions of groundwater movement.

\section{Establishing Baseline Water-Quality Conditions}

To establish baseline water-quality conditions in the study area, new and existing water-quality data were compiled and analyzed. Existing water-quality data were compiled from the USGS National Water Information System (NWIS) database and the Utah Safe Drinking Water Information System (SDWIS) database to describe groundwater quality in the Bluff area. Some sites contain data in both databases. These datasets contain records of groundwater-quality analyses of samples collected in and around Bluff from 1933 to 2017. Data from seven samples of oil-field brine (produced water) collected from water storage tanks at injection facilities and that represent composite samples of mixed waters from numerous production wells, were compiled from Spangler and others (1996). Mean annual oxygen and hydrogen isotope ratios of precipitation in Bluff and in Cortez and Silverton, Colorado, were calculated at WaterIsotopes.org (Waterisotopes Database, accessed April 16, 2018, at http://wateriso.utah.edu/ waterisotopes/pages/information/oipc_info.html).

WaterIsotopes.org calculates the long-term average monthly and annual isotopic composition of precipitation based on global precipitation oxygen and hydrogen isotope data (Bowen and Wilkinson, 2002; Bowen and Revenaugh, 2003;
Bowen and others, 2005). These locations were selected because precipitation at these locations likely contributes to runoff that flows into the San Juan River. The isotope ratio data for these locations are general estimates and are meant to provide context for the isotope ratios of samples in the study area. Oxygen and hydrogen isotope ratios for wells were obtained over a larger area than the general chemistry samples because there were only a few isotope values from sites where general chemistry samples were obtained. The oxygen and hydrogen isotope ratios from a broader area highlight largerscale hydrologic processes, whereas the general chemistry data from a more localized area around Bluff represent the waterquality characteristics of Bluff's drinking-water supply.

Water-quality data for wells outside the town limits of Bluff were limited, and some key water-quality parameters useful for identifying and determining sources of constituents associated with hydrocarbon production had not been sampled for. Additional water samples, therefore, were collected from five wells completed in aquifers used for drinking water and one site on the San Juan River. Samples were analyzed for major ions, selected trace elements, nutrients, stable oxygen-18 and hydrogen (deuterium) isotope ratios, and dissolved gases including ethane, propane, and methane concentrations (and carbon-13 and hydrogen isotope ratios of methane) to establish baseline data for future water-quality monitoring. Major ions and trace elements were also selected to complement continuous USGS water-quality sampling at the San Juan River at Bluff (USGS site number 09379500) streamgaging station. Sample isotope values are reported using $\delta$ notation expressed as

$$
\delta R=\left(\frac{R_{\text {sample }}}{R_{\text {standard }}}-1\right) \times 1,000
$$

where

$$
\begin{gathered}
\delta R \quad \begin{array}{l}
\text { is the value for a specific isotope in the } \\
\text { sample, }
\end{array} \\
R_{\text {sample }} \quad \begin{array}{l}
\text { is the ratio of the less abundant isotope to the } \\
\text { common isotope for a specific element in } \\
\text { the sample, and }
\end{array} \\
R_{\text {standard }} \quad \begin{array}{l}
\text { is the ratio of the less abundant isotope to the } \\
\text { common isotope for the same element in } \\
\text { the reference standard. }
\end{array}
\end{gathered}
$$

Results are reported in permil (\%), which is equivalent to parts per thousand. Oxygen and hydrogen isotopic results are reported in permil relative to VSMOW (Vienna Standard Mean Ocean Water; Coplen, 1994).

Sampling was done December 4 to 7, 2017, and followed procedures described in the National Field Manual (U.S. Geological Survey, variously dated). Dissolved hydrocarbon gas samples were collected in IsoFlasks, following the procedures described by Isotech, and analyzed at the Isotech laboratory in Champagne, Illinois. Wells with prior water-quality or water-level data and wells that 
contribute substantially to the public water supply were sampled. One well north of the proposed production wells (USGS site number 372408109312301) was sampled because it is unlikely to experience effects from the installation of the proposed production wells and could serve as a comparison to differentiate natural changes in the hydrologic system. This well is upgradient from the proposed production wells making it difficult for groundwater and potential contaminants to move toward this well. General chemistry, dissolved hydrocarbon gas, hydrogen and oxygen isotope, and water-level data for this site are summarized in table 1 . Holding times for nitratenitrite samples collected from the well exceeded the 30-day limit by 3 to 5 days. Results of the analyses are presented, however, because they are generally within the range of existing nitrate-nitrite concentrations in the study area.

Chemical signatures of water can be used to determine whether produced waters or other fluids have mixed with freshwater, such as that withdrawn for public supply in Bluff. Most of the oil and gas production is within the Paradox Member of the Hermosa Formation (fig. 2). A limited amount of data on the chemistry of water from these formations were compiled from Spangler and others (1996). Permission to collect new samples of produced water was not granted; therefore, no new samples were obtained.

\section{Determining Groundwater Flow Direction, Travel Times, and Age}

Understanding the direction of groundwater flow can be used to determine where potential contaminants might move and to clarify the connection between the principal aquifers and the San Juan River. Water-level data from 2012 to 2017 for six wells in the study area were used to develop a potentiometric surface map for the study area to determine the direction of groundwater flow. Water levels at five of the six wells were from 2017. However, the water level at one well was from 2012. Water levels measured on different dates were used because relatively few measurements exist, and the spatial extent of the wells is limited. The potentiometric surface developed here could be different than a potentiometric surface developed from water levels measured on the same date. The altitude of the water table at each well was determined by subtracting the depth to water in each well from the land-surface altitude at that well, which was then used to develop a potentiometric surface map using kriging in ArcMap (Esri, version 10.5, https://www.esri.com/en-us/home). ArcMap is a program to represent and analyze geospatial information. Kriging was selected because it produced the most hydrologically realistic potentiometric surface. Other attempted methods (for example, inverse distance weighted and natural neighbor techniques) produced potentiometric surfaces with unusual distributions of the water-level altitude data points. The surface created with kriging was then contoured, and the contour lines were manually smoothed to reduce edge effects caused by the limited spatial extent of the wells.
Groundwater travel times can be used to estimate how quickly contaminants potentially could move through an aquifer toward drinking-water wells. Published Glen Canyon Group aquifer properties, along with the potentiometric surface map, were used to estimate groundwater travel times. Hydraulic conductivity, a measure of a materials ability to transmit water, has been estimated from aquifer tests to be between 0.02 and 0.34 feet per day ( $\mathrm{ft} / \mathrm{d})$ in the $\mathrm{N}$ aquifer (Avery, 1986).

Travel time was calculated as

$$
T=\frac{d}{\left(\frac{K}{\Phi_{e}}\right)\left(\frac{\Delta h}{\Delta l}\right)}
$$

where

$\begin{aligned} T & \text { is travel time, in days, } \\ d & \text { is the length of a flow-line segment, in feet, } \\ K & \text { is hydraulic conductivity, in feet per day, } \\ \Phi_{e} & \text { is the effective porosity, unitless, and } \\ \partial h / \partial l & \text { is the hydraulic gradient, in foot per foot. }\end{aligned}$

For estimates of travel time in this report, the maximum hydraulic conductivity of $0.34 \mathrm{ft} / \mathrm{d}$ was used. Effective porosity was estimated to be between 0.1 and 0.3 , on the basis of reported Navajo Sandstone effective porosities from the Virgin River basin in southwestern Utah (Cordova, 1978; Heilweil and Solomon, 2004; Marston and Heilweil, 2012). The hydraulic gradient was determined by taking the average slope of the potentiometric surface. The flow-line segment length was measured from the potentiometric surface map.

Radiocarbon ages of groundwater in Bluff were calculated from alkalinity, $\mathrm{pH}$, water temperature, and carbon isotope data of dissolved inorganic carbon species using the Tamers (1975) and Fontes and Garnier (1979) inorganic adjustment models. Radiocarbon ages are calculated from the known decay (half-life) of carbon-14 $\left({ }^{14} \mathrm{C}\right)$ and adjusted because of changes in ${ }^{14} \mathrm{C}$ activity from reactions with carbon dioxide $\left(\mathrm{CO}_{2}\right)$ and carbonate minerals in the unsaturated and saturated zones in the subsurface. The radiocarbon-age adjustment models require values of ${ }^{14} \mathrm{C}$ and $\delta^{13} \mathrm{C}$ of soil gas $\mathrm{CO}_{2}$ and carbonate minerals that can react with, or add to, the dissolved inorganic carbon in groundwater. The ${ }^{14} \mathrm{C}$ activity of soil $\mathrm{CO}_{2}$ was assumed to be 100 percent modern carbon (pMC) because of the low ${ }^{14} \mathrm{C}$ activities of the groundwater samples, which indicate that the samples pre-date the atomic bomb testing in the 1950s (Fontes and Garnier, 1979). The ${ }^{14} \mathrm{C}$ activity of carbonate minerals was assumed to be $0 \mathrm{pMC}$ (Plummer and Sprinkle, 2001). The $\delta^{13} \mathrm{C}$ of marine carbonate minerals is typically between 0 plus or minus 2 permil (Clark and Fritz, 1997; Gardner and Heilweil, 2014). Cerling and others (1991) reported the soil gas $\delta^{13} \mathrm{C}$ of $\mathrm{CO}_{2}$ to be -23.3 permil in the Wasatch Mountains of Utah. The apparent ${ }^{14} \mathrm{C}$ ages were compared to estimated travel times. 
Table 1. Locations of groundwater and surface-water sites in and around Bluff, Utah, and date range for which general chemistry, dissolved hydrocarbon gas, hydrogen and oxygen isotope ratio, and water-level data were compiled or collected.

[Latitude and longitude geographic coordinates in decimal degrees. Abbreviations: mm/dd/yyyy, month/day/year; NWIS, National Water Information System; SDWIS, Safe Drinking Water Information System; USGS, U.S. Geological Survey; WM, White Mesa; NA, not applicable; —, no data]

\begin{tabular}{|c|c|c|c|c|c|c|c|c|c|}
\hline Database & Station number & Site name & Latitude & Longitude & $\begin{array}{c}\text { Date of first } \\
\text { sample } \\
\text { (mm/dd/yyyy) }\end{array}$ & $\begin{array}{c}\text { Date of last } \\
\text { sample } \\
\text { (mm/dd/yyyy) }\end{array}$ & Site type & $\begin{array}{l}\text { Well } \\
\text { depth } \\
\text { (feet) }\end{array}$ & $\begin{array}{c}\text { Number } \\
\text { of } \\
\text { samples }\end{array}$ \\
\hline \multicolumn{10}{|c|}{ General chemistry } \\
\hline NWIS & 371542109364401 & San Juan River at Sand Island & 37.261556 & -109.612222 & $12 / 04 / 17$ & $12 / 04 / 17$ & Stream & NA & 20 \\
\hline NWIS & 371545109364402 & (D-40-21)33dbc- 2 & 37.264583 & -109.611917 & $09 / 15 / 11$ & $09 / 07 / 17$ & Groundwater & 260 & 63 \\
\hline NWIS & 371630109313001 & (D-40-22)30aad- 2 & 37.275000 & -109.525676 & $05 / 01 / 59$ & $05 / 01 / 59$ & Groundwater & 27 & 8 \\
\hline NWIS & 371643109335501 & (D-40-21)26daa- 2 & 37.278612 & -109.565955 & $11 / 19 / 82$ & $11 / 19 / 82$ & Groundwater & 300 & 11 \\
\hline NWIS & 371652109340401 & (D-40-21)26ada- 1 & 37.281112 & -109.568455 & $04 / 14 / 82$ & $04 / 14 / 82$ & Groundwater & 700 & 8 \\
\hline NWIS & 371653109312301 & (D-40-22)29bdb- 1 & 37.281389 & -109.523732 & $11 / 21 / 82$ & $11 / 21 / 82$ & Groundwater & 325 & 11 \\
\hline NWIS & 371657109331301 & (D-40-21)25adb- 1 & 37.282501 & -109.554288 & $11 / 19 / 82$ & $11 / 19 / 82$ & Groundwater & 590 & 11 \\
\hline NWIS & 371657109331901 & (D-40-21)25acd- 1 & 37.282501 & -109.555955 & $07 / 23 / 82$ & $08 / 23 / 12$ & Groundwater & 450 & 115 \\
\hline NWIS & 371700109314501 & (D-40-22)30aad- 1 & 37.283334 & -109.529843 & $10 / 24 / 57$ & $11 / 21 / 82$ & Groundwater & 440 & 44 \\
\hline NWIS & 371701109324001 & (D-40-21)25aac- 1 & 37.283612 & -109.545121 & $05 / 04 / 82$ & $05 / 04 / 82$ & Groundwater & 550 & 12 \\
\hline NWIS & 371703109323001 & (D-40-22)30bbd- 1 & 37.284167 & -109.542343 & $09 / 10 / 58$ & $11 / 21 / 82$ & Groundwater & 600 & 20 \\
\hline SDWIS and NWIS & 371706109320001 & 1-96 well & 37.284888 & -109.530732 & $12 / 13 / 94$ & $12 / 09 / 12$ & Groundwater & - & 52 \\
\hline SDWIS and NWIS & 371706109321901 & 2-96 well & 37.284852 & -109.538627 & $12 / 13 / 94$ & $12 / 09 / 12$ & Groundwater & - & 51 \\
\hline NWIS & 371707109304301 & (D-40-22)29aaa- 1 & 37.285278 & -109.512620 & $05 / 21 / 58$ & $12 / 05 / 17$ & Groundwater & 599 & 46 \\
\hline SDWIS and NWIS & 371707109323201 & Corral well & 37.285988 & -109.542556 & $12 / 13 / 94$ & $12 / 06 / 17$ & Groundwater & - & 101 \\
\hline NWIS & 371708109331301 & (D-40-21)25aab- 1 & 37.285556 & -109.554288 & $11 / 13 / 33$ & $11 / 13 / 33$ & Groundwater & 300 & 3 \\
\hline SDWIS and NWIS & 371711109335401 & 1-94 well & 37.286389 & -109.565000 & $12 / 13 / 94$ & $12 / 06 / 17$ & Groundwater & - & 93 \\
\hline NWIS & 371712109334301 & (D-40-21)25bab- 1 & 37.286667 & -109.562621 & $11 / 19 / 82$ & $11 / 19 / 82$ & Groundwater & 300 & 11 \\
\hline NWIS & 371715109322301 & (D-40-22)19cdc- 1 & 37.287500 & -109.540399 & $11 / 21 / 82$ & $11 / 21 / 82$ & Groundwater & 350 & 11 \\
\hline NWIS & 371716109325501 & (D-40-22)30bbb- 1 & 37.287778 & -109.549288 & $11 / 13 / 33$ & $12 / 05 / 17$ & Groundwater & 825 & 436 \\
\hline NWIS & 371717109330201 & (D-40-21)25aba- 1 & 37.288056 & -109.551232 & $05 / 04 / 82$ & $05 / 04 / 82$ & Groundwater & 825 & 2 \\
\hline NWIS & 371730109320001 & (D-40-22)19 -S1 & 37.291667 & -109.534010 & $04 / 29 / 59$ & $04 / 29 / 59$ & Spring & NA & 2 \\
\hline NWIS & 371735109304201 & (D-40-22)20ddd-S1 & 37.293056 & -109.512343 & $04 / 26 / 47$ & $05 / 01 / 59$ & Spring & NA & 8 \\
\hline NWIS & 371747109275301 & (D-40-22)23aca- 1 & 37.296944 & -109.464564 & $08 / 26 / 92$ & $08 / 26 / 92$ & Groundwater & - & 14 \\
\hline NWIS & 371803109340401 & (D-40-21)23aad- 1 & 37.300834 & -109.568455 & $11 / 19 / 82$ & $11 / 19 / 82$ & Groundwater & 840 & 11 \\
\hline NWIS & 372306109322801 & (D-39-22)19bbd- 1 & 37.385001 & -109.541788 & $04 / 29 / 82$ & $04 / 29 / 82$ & Groundwater & 1,450 & 12 \\
\hline NWIS & 372338109313001 & (D-39-22)17cbd- 1 & 37.393889 & -109.525677 & $06 / 13 / 82$ & $06 / 13 / 82$ & Groundwater & 820 & 12 \\
\hline NWIS & 372408109312301 & (D-39-22)17bab- 1 & 37.402223 & -109.523733 & $09 / 18 / 82$ & $12 / 07 / 17$ & Groundwater & 1,350 & 32 \\
\hline SDWIS & Arsenic treatment plant & Arsenic treatment plant & 37.285972 & -109.542741 & $05 / 14 / 15$ & $12 / 20 / 17$ & Groundwater & - & 3 \\
\hline SDWIS & Sand Island well & Sand Island well & 37.264646 & -109.612011 & $08 / 27 / 01$ & $10 / 02 / 17$ & Groundwater & - & 41 \\
\hline
\end{tabular}


Table 1. Locations of groundwater and surface-water sites in and around Bluff, Utah, and date range for which general chemistry, dissolved hydrocarbon gas, hydrogen and oxygen isotope ratio, and water-level data were compiled or collected.—Continued

[Latitude and longitude geographic coordinates in decimal degrees. Abbreviations: mm/dd/yyyy, month/day/year; NWIS, National Water Information System; SDWIS, Safe Drinking Water Information System; USGS, U.S. Geological Survey; WM, White Mesa; NA, not applicable; —, no data]

\begin{tabular}{|c|c|c|c|c|c|c|c|c|c|}
\hline Database & Station number & Site name & Latitude & Longitude & $\begin{array}{l}\text { Date of first } \\
\text { sample } \\
\text { (mm/dd/yyyy) }\end{array}$ & $\begin{array}{c}\text { Date of last } \\
\text { sample } \\
\text { (mm/dd/yyyy) }\end{array}$ & Site type & $\begin{array}{l}\text { Well } \\
\text { depth } \\
\text { (feet) }\end{array}$ & $\begin{array}{c}\text { Number } \\
\text { of } \\
\text { samples }\end{array}$ \\
\hline \multicolumn{10}{|c|}{ Dissolved hydrocarbon gases } \\
\hline NWIS & 371542109364401 & San Juan River at Sand Island & 37.2615556 & -109.612222 & $12 / 04 / 17$ & $12 / 04 / 17$ & Stream & NA & 1 \\
\hline NWIS & 371707109304301 & (D-40-22)29aaa- 1 & 37.2852781 & -109.512620 & $12 / 05 / 17$ & $12 / 05 / 17$ & Groundwater & 599 & 2 \\
\hline NWIS & 371716109325501 & (D-40-22)30bbb- 1 & 37.2877783 & -109.549288 & $12 / 05 / 17$ & $12 / 05 / 17$ & Groundwater & 825 & 1 \\
\hline NWIS & 371707109323201 & Corral well & 37.2859880 & -109.542556 & $12 / 06 / 17$ & $12 / 06 / 17$ & Groundwater & - & 1 \\
\hline NWIS & 371711109335401 & 1-94 well & 37.2863889 & -109.565000 & $12 / 13 / 94$ & $12 / 06 / 17$ & Groundwater & - & 1 \\
\hline NWIS & 372408109312301 & (D-39-22)17bab- 1 & 37.4022228 & -109.523733 & $09 / 18 / 82$ & $12 / 07 / 17$ & Groundwater & 1,350 & 1 \\
\hline \multicolumn{10}{|c|}{ Hydrogen and oxygen isotope ratios } \\
\hline NWIS & 9378600 & Montezuma Creek near Bluff, UT & 37.299998 & -109.300671 & $04 / 20 / 94$ & $04 / 20 / 94$ & Stream & NA & 1 \\
\hline NWIS & 371542109364401 & San Juan River at Sand Island & 37.261556 & -109.612222 & $12 / 04 / 17$ & $12 / 04 / 17$ & Stream & NA & 1 \\
\hline NWIS & 371621109211001 & (D-40-23)27baa- 1 & 37.286110 & -109.377895 & $08 / 25 / 92$ & $08 / 25 / 92$ & Groundwater & 672 & 1 \\
\hline NWIS & 371707109304301 & (D-40-22)29aaa- 1 & 37.285278 & -109.512620 & $12 / 05 / 17$ & $12 / 05 / 17$ & Groundwater & 599 & 1 \\
\hline NWIS & 371707109323201 & (D-40-22)30bab- 1 & 37.285889 & -109.542556 & $08 / 02 / 17$ & $12 / 06 / 17$ & Groundwater & 580 & 2 \\
\hline NWIS & 371711109335401 & 1-94 well & 37.286389 & -109.565000 & $12 / 06 / 17$ & $12 / 06 / 17$ & Groundwater & - & 1 \\
\hline NWIS & 371716109325501 & (D-40-22)30bbb- 1 & 37.287778 & -109.549288 & $12 / 05 / 17$ & $12 / 05 / 17$ & Groundwater & 825 & 1 \\
\hline NWIS & 371728109233901 & (D-40-23)21dbc- 1 & 37.292777 & -109.392895 & $08 / 28 / 92$ & $08 / 28 / 92$ & Groundwater & 777 & 1 \\
\hline NWIS & 371735109243701 & $(\mathrm{D}-40-23) 20 \mathrm{db}-1$ & 37.293055 & -109.410951 & $06 / 24 / 92$ & $06 / 24 / 92$ & Groundwater & 5,520 & 1 \\
\hline NWIS & 371747109275301 & (D-40-22)23aca- 1 & 37.296944 & -109.464564 & $08 / 26 / 92$ & 08/26/92 & Groundwater & - & 1 \\
\hline NWIS & 371749109184701 & (D-40-24)19ada- 1 & 37.296943 & -109.313727 & $10 / 09 / 89$ & $10 / 09 / 89$ & Groundwater & - & 1 \\
\hline NWIS & 371809109180301 & (D-40-24)17dcd- 1 & 37.302498 & -109.301504 & $06 / 23 / 92$ & $06 / 23 / 92$ & Groundwater & - & 1 \\
\hline NWIS & 371818109180401 & (D-40-24)17dca- 1 & 37.304998 & -109.301782 & $06 / 23 / 92$ & $06 / 23 / 92$ & Groundwater & - & 1 \\
\hline NWIS & 371830109175001 & (D-40-24)17dbd- 1 & 37.306943 & -109.301504 & $06 / 06 / 84$ & $06 / 06 / 84$ & Groundwater & 925 & 1 \\
\hline NWIS & 371848109175101 & (D-40-24)17aac- 1 & 37.313332 & -109.297615 & $08 / 25 / 92$ & $08 / 25 / 92$ & Groundwater & - & 1 \\
\hline NWIS & 372010109233001 & (D-40-23) 4dbd- 1 & 37.336111 & -109.392340 & $04 / 03 / 93$ & $04 / 03 / 93$ & Groundwater & - & 1 \\
\hline NWIS & 372020109230801 & (D-40-23) 3bcc- 1 & 37.338888 & -109.384562 & $06 / 24 / 92$ & $06 / 24 / 92$ & Groundwater & - & 1 \\
\hline NWIS & 372028109231601 & (D-40-23) 4ada- 1 & 37.341666 & -109.385951 & $06 / 24 / 92$ & $06 / 24 / 92$ & Groundwater & - & 1 \\
\hline NWIS & 372408109312301 & (D-39-22)17bab- 1 & 37.402223 & -109.523733 & $12 / 07 / 17$ & $12 / 07 / 17$ & Groundwater & 1,350 & 1 \\
\hline NWIS & 372756109280901 & (D-38-22)23cda- 1 WM South well & 37.464194 & -109.467750 & $09 / 11 / 07$ & $11 / 12 / 08$ & Groundwater & 1,739 & 4 \\
\hline NWIS & 372817109275701 & (D-38-22)23acb- 1 WM North well & 37.471861 & -109.466194 & $09 / 11 / 07$ & $11 / 11 / 08$ & Groundwater & 1,385 & 4 \\
\hline NWIS & 372832109282001 & (D-38-22)23bba-S1 Right Hand Fork seep & 37.475472 & -109.472333 & $03 / 12 / 08$ & $03 / 12 / 08$ & Spring & NA & 1 \\
\hline
\end{tabular}


Table 1. Locations of groundwater and surface-water sites in and around Bluff, Utah, and date range for which general chemistry, dissolved hydrocarbon gas, hydrogen and oxygen isotope ratio, and water-level data were compiled or collected.-Continued

[Latitude and longitude geographic coordinates in decimal degrees. Abbreviations: mm/dd/yyyy, month/day/year; NWIS, National Water Information System; SDWIS, Safe Drinking Water Information System; USGS, U.S. Geological Survey; WM, White Mesa; NA, not applicable; —, no data]

\begin{tabular}{|c|c|c|c|c|c|c|c|c|c|}
\hline Database & Station number & Site name & Latitude & Longitude & $\begin{array}{c}\text { Date of first } \\
\text { sample } \\
\text { (mm/dd/yyyy) }\end{array}$ & $\begin{array}{c}\text { Date of last } \\
\text { sample } \\
\text { (mm/dd/yyyy) }\end{array}$ & Site type & $\begin{array}{l}\text { Well } \\
\text { depth } \\
\text { (feet) }\end{array}$ & $\begin{array}{c}\text { Number } \\
\text { of } \\
\text { samples }\end{array}$ \\
\hline \multicolumn{10}{|c|}{ Hydrogen and oxygen isotope ratios-Continued } \\
\hline NWIS & 372838109200001 & (D-38-23)13ddc- 1 & 37.477222 & -109.334005 & $04 / 21 / 94$ & $04 / 21 / 94$ & Groundwater & 3,680 & 1 \\
\hline NWIS & 372930109310701 & $\begin{array}{l}\text { (D-38-22) 8dcd- } 1 \text { WM West monitoring } \\
\text { well }\end{array}$ & 37.491583 & -109.518583 & $09 / 11 / 07$ & $11 / 13 / 08$ & Groundwater & 110 & 5 \\
\hline NWIS & 372943109293201 & $\begin{array}{l}\text { (D-38-22)10cbc Anasazi Pond near } \\
\text { spillway }\end{array}$ & 37.495222 & -109.492139 & 09/18/08 & 09/18/08 & Lake & NA & 1 \\
\hline NWIS & 372954109293601 & $\begin{array}{l}\text { (D-38-22)10bcc- } 1 \text { WM East monitoring } \\
\text { well }\end{array}$ & 37.498222 & -109.493417 & 09/11/07 & $11 / 13 / 08$ & Groundwater & 90 & 5 \\
\hline NWIS & 373006109312301 & (D-38-22) 8bad-S1 Ruin Spring & 37.501667 & -109.523056 & $09 / 11 / 07$ & $11 / 11 / 08$ & Spring & NA & 6 \\
\hline \multicolumn{10}{|c|}{ Water levels } \\
\hline USGS & 371657109331901 & (D-40-21)25acd- 1 & 37.282501 & -109.555955 & NA & $03 / 22 / 2012$ & Groundwater & 450 & 1 \\
\hline USGS & 371707109304301 & (D-40-22)29aaa- 1 & 37.285278 & -109.512620 & NA & $12 / 05 / 2017$ & Groundwater & 599 & 1 \\
\hline USGS & 371716109325501 & (D-40-22)30bbb- 1 & 37.287778 & -109.549288 & NA & $03 / 21 / 2017$ & Groundwater & 825 & 1 \\
\hline USGS & 371740109310001 & (D-40-22)20bdc- 1 & 37.294445 & -109.517343 & NA & $03 / 21 / 2017$ & Groundwater & 240 & 1 \\
\hline USGS & 372300109292501 & (D-39-22)22bcd- 1 & 37.383334 & -109.490954 & NA & $12 / 07 / 2017$ & Groundwater & 475 & 1 \\
\hline USGS & 372408109312301 & (D-39-22)17bab- 1 & 37.402223 & -109.523733 & NA & $12 / 07 / 2017$ & Groundwater & 1,350 & 1 \\
\hline
\end{tabular}




\section{Groundwater Hydrology and Water Quality}

The following subsections summarize the results of the data analysis completed for this study to determine baseline water-quality conditions and groundwater flow direction, age, and travel times.

\section{Physical Properties, Major Ions, Trace Elements, and Nutrients}

The groundwater quality in and around Bluff, Utah, is generally good. The physical properties of water samples collected for this study are shown in table 2. Concentrations of major ions, trace elements, and nutrients in samples collected for this study are shown in table 3 . To put the water-quality conditions for this study in context, they were compared to (1) existing water-quality data from the NWIS and SDWIS databases for wells no deeper than 2,000 ft, (2) the San Juan River, and (3) springs in the study area (figs. 3 and 4). The water-quality data also were compared to the U.S. Environmental Protection Agency maximum contaminant levels (MCLs) or secondary maximum contaminant levels (SMCLs) when concentrations approached or exceeded these standards (U.S. Environmental Protection Agency, 2018). Maximum contaminant levels are enforceable standards for contaminants that could affect human health. Secondary maximum contaminant levels are unenforceable guidelines for contaminants that could cause cosmetic or aesthetic effects.

The concentrations of major ions, trace elements, and nutrients, and physical properties of samples collected previously and samples collected during this study were below the MCLs or SMCLs, except for $\mathrm{pH}$ and concentrations of arsenic, iron, sulfate, and dissolved solids in a few samples. Physical properties and solute concentrations of samples collected for this study generally fall within the range of existing values and concentrations. The MCL for arsenic is 0.01 milligrams per liter $(\mathrm{mg} / \mathrm{L}$; U.S. Environmental Protection Agency, 2018), which is equivalent to 10 micrograms per liter $(\mu \mathrm{g} / \mathrm{L})$. Micrograms per liter are also included in this report because arsenic is commonly reported in $\mu \mathrm{g} / \mathrm{L}$ in regulatory documents and in the scientific literature. Arsenic concentrations ranged from 0.00046 to $0.0701 \mathrm{mg} / \mathrm{L}(0.46$ to $70.1 \mu \mathrm{g} / \mathrm{L})$, with a median concentration of $0.009 \mathrm{mg} / \mathrm{L}(9.0 \mu \mathrm{g} / \mathrm{L})$, a mean concentration of $0.01586 \mathrm{mg} / \mathrm{L}(15.86 \mu \mathrm{g} / \mathrm{L})$, and a standard deviation of $0.01810 \mathrm{mg} / \mathrm{L}(18.10 \mu \mathrm{g} / \mathrm{L}$; number of samples $(\mathrm{n})=66)$. The $\mathrm{SMCL}$ for iron is $0.3 \mathrm{mg} / \mathrm{L}$. Iron concentrations ranged from less than 0.003 to $0.96 \mathrm{mg} / \mathrm{L}$, with a median concentration of $0.01 \mathrm{mg} / \mathrm{L}$, a mean concentration of $0.11 \mathrm{mg} / \mathrm{L}$, and a standard deviation of $0.28 \mathrm{mg} / \mathrm{L}(\mathrm{n}=44)$. The SMCL for sulfate is $250 \mathrm{mg} / \mathrm{L}$. Sulfate concentrations ranged from 26 to $1,170 \mathrm{mg} / \mathrm{L}$, with a median concentration of $48 \mathrm{mg} / \mathrm{L}$, a mean concentration of $62 \mathrm{mg} / \mathrm{L}$, and a standard deviation of $115 \mathrm{mg} / \mathrm{L}(\mathrm{n}=105)$. The SMCL for $\mathrm{pH}$ is 6.5 to 8.5 . The $\mathrm{pH}$ ranged from 7.5 to 9.6 , with a median of 8.8 , a mean of 8.7, and a standard deviation of $0.4(\mathrm{n}=87)$. The SMCL for total dissolved solids is $500 \mathrm{mg} / \mathrm{L}$. Dissolved-solids concentrations ranged from 166 to $726 \mathrm{mg} / \mathrm{L}$, with a median concentration of $270 \mathrm{mg} / \mathrm{L}$, a mean concentration of $303 \mathrm{mg} / \mathrm{L}$, and a standard deviation of $107 \mathrm{mg} / \mathrm{L}(\mathrm{n}=56)$. In water samples collected from the Paradox Member, dissolved-solids concentrations ranged from 6,730 to $381,436 \mathrm{mg} / \mathrm{L}$, chloride ranged from 3,660 to $238,000 \mathrm{mg} / \mathrm{L}$, and sulfate ranged from 145 to $4,601 \mathrm{mg} / \mathrm{L}$ (Whitfield and others, 1983). Summary statistics for an expanded list of analytes with respect to primary and secondary drinking-water standards are shown in table 4. Only one measurement of bromate, a byproduct of drinking-water disinfection, has been made, and it exceeded the MCL of $0.01 \mathrm{mg} / \mathrm{L}$ at $0.03 \mathrm{mg} / \mathrm{L}$.

Bromide and chloride concentrations can be useful in identifying sources of groundwater that have potentially mixed with freshwater. Bromide and chloride concentrations in water samples collected from the principal bedrock aquifers, San Juan River, and the adjacent alluvial aquifer were compared to bromide and chloride concentrations in oil-field brines (Spangler and others, 1996; fig. 5). Bromide concentrations in water samples collected from study sites ranged from 0.01 to $0.056 \mathrm{mg} / \mathrm{L}$, with a median concentration of $0.023 \mathrm{mg} / \mathrm{L}$, a mean concentration of $0.023 \mathrm{mg} / \mathrm{L}$, and standard deviation of $0.01 \mathrm{mg} / \mathrm{L}(\mathrm{n}=20)$. Chloride concentrations in water samples collected from study sites ranged from 0.8 to $125 \mathrm{mg} / \mathrm{L}$, with a median concentration of $4.0 \mathrm{mg} / \mathrm{L}$, a mean concentration of $9.4 \mathrm{mg} / \mathrm{L}$, and standard deviation of $14.8 \mathrm{mg} / \mathrm{L}(\mathrm{n}=86)$. The bromide and chloride concentrations in the principal bedrock aquifers, San Juan River, and the adjacent alluvial aquifer are distinct from the bromide and chloride concentrations in oilfield brines, which ranged from 200 to $480 \mathrm{mg} / \mathrm{L}$ and 44,000 to $110,000 \mathrm{mg} / \mathrm{L}$, respectively (Spangler and others, 1996). This difference can be used to determine if oil-field brines could be a source of these constituents in the Bluff water supply.

Bromide-to-chloride ratios can also be useful in assessing changes to groundwater, such as from mixing. Of the three sites where multiple bromide and chloride values are available, the calculated bromide-to-chloride ratios have remained relatively stable. The maximum change in the bromide-to-chloride ratio occurred at USGS site number 371657109331901 . The ratio in water from this well increased from 0.04 to 0.11 between 2005 and 2012 because of an increase in bromide concentration from $0.01 \mathrm{mg} / \mathrm{L}$ to $0.021 \mathrm{mg} / \mathrm{L}$ and a decrease in chloride concentration from $2.19 \mathrm{mg} / \mathrm{L}$ to $1.89 \mathrm{mg} / \mathrm{L}$. 
Table 2. Physical properties of water samples collected from selected wells in the principal bedrock aquifers and from the San Juan River in and around Bluff, Utah, December 4 to 7, 2017.

$[\mathrm{mm} / \mathrm{dd} / \mathrm{yyyy}$, month/day/year; - , no data $]$

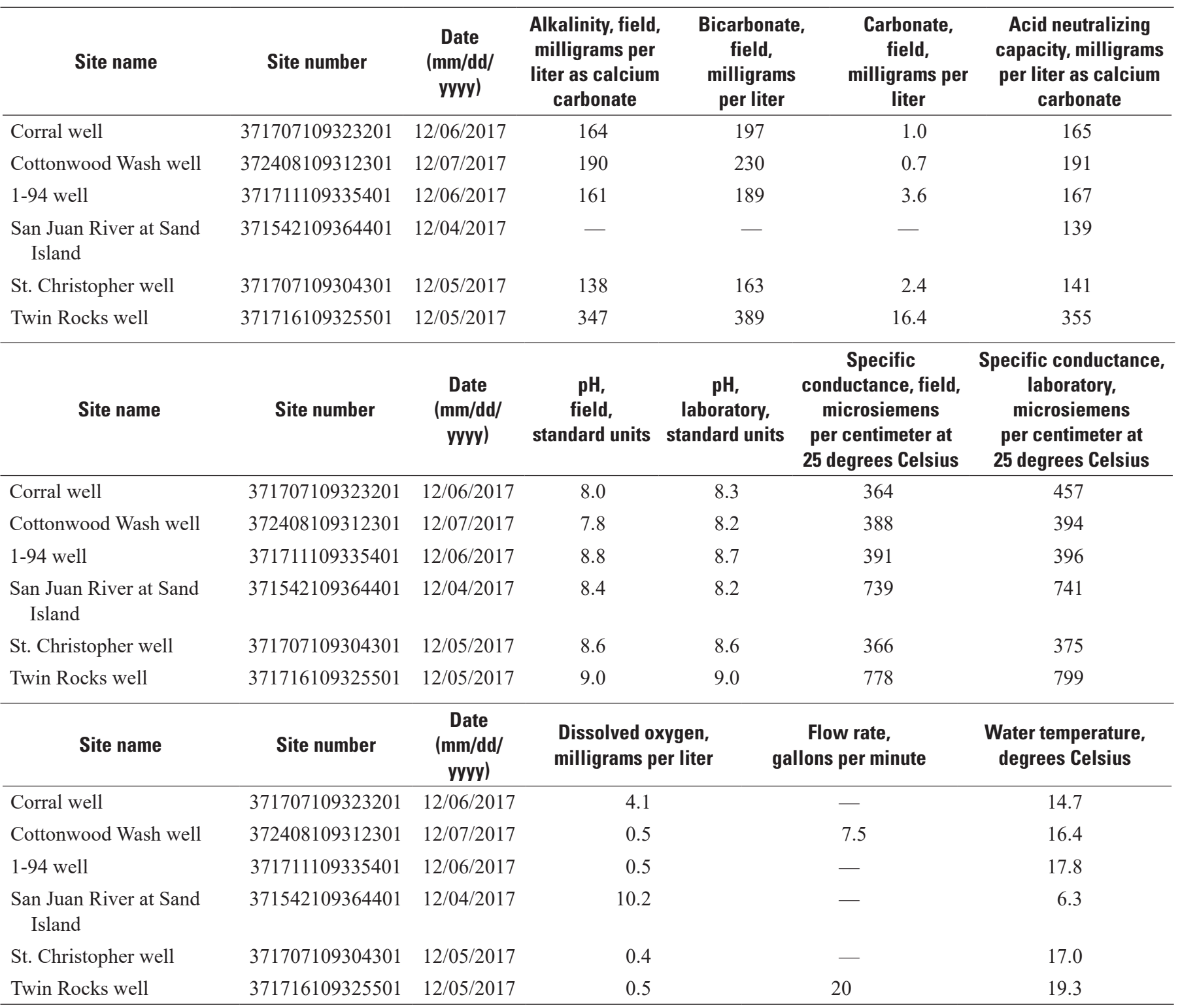


Table 3. Concentrations of major ions, and selected trace elements and nutrients in water samples collected from selected wells in the principal bedrock aquifers and from the San Juan River in and around Bluff, Utah, December 4 to 7, 2017.

[mm/dd/yyyy, month/day/year; ROE, residue on evaporation at 180 degrees Celsius; $<$, less than]

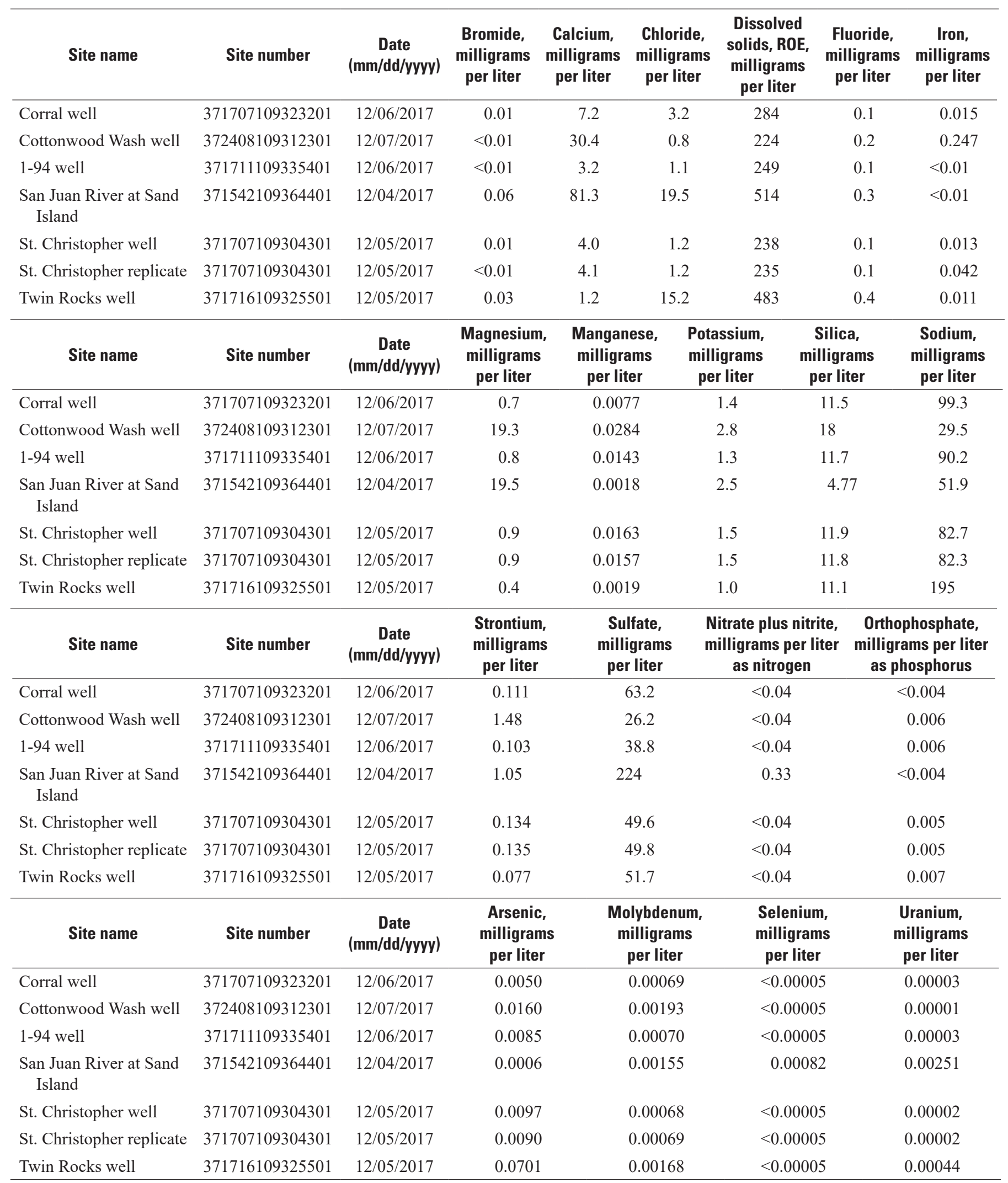



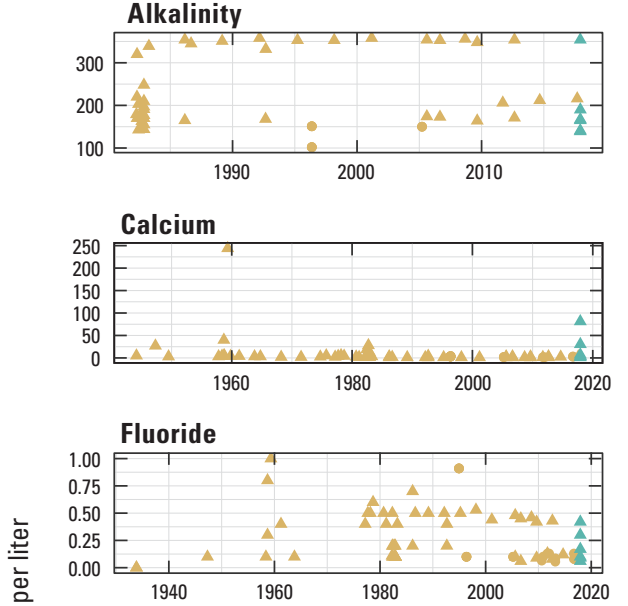

Manganese
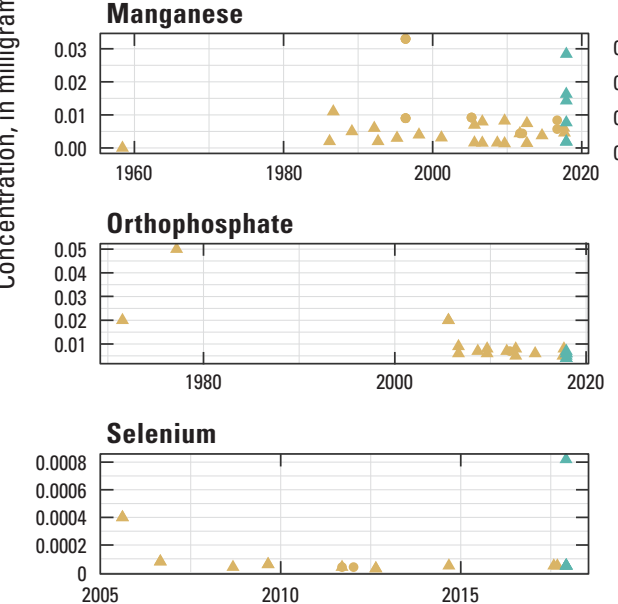

Sulfate

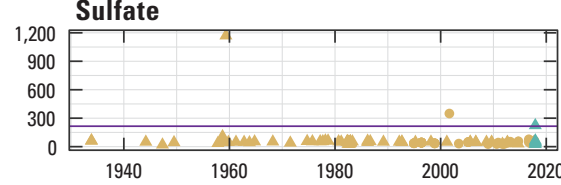

Drinking-water standard

- Maximum contaminant leve

- Secondary maximum contaminant level
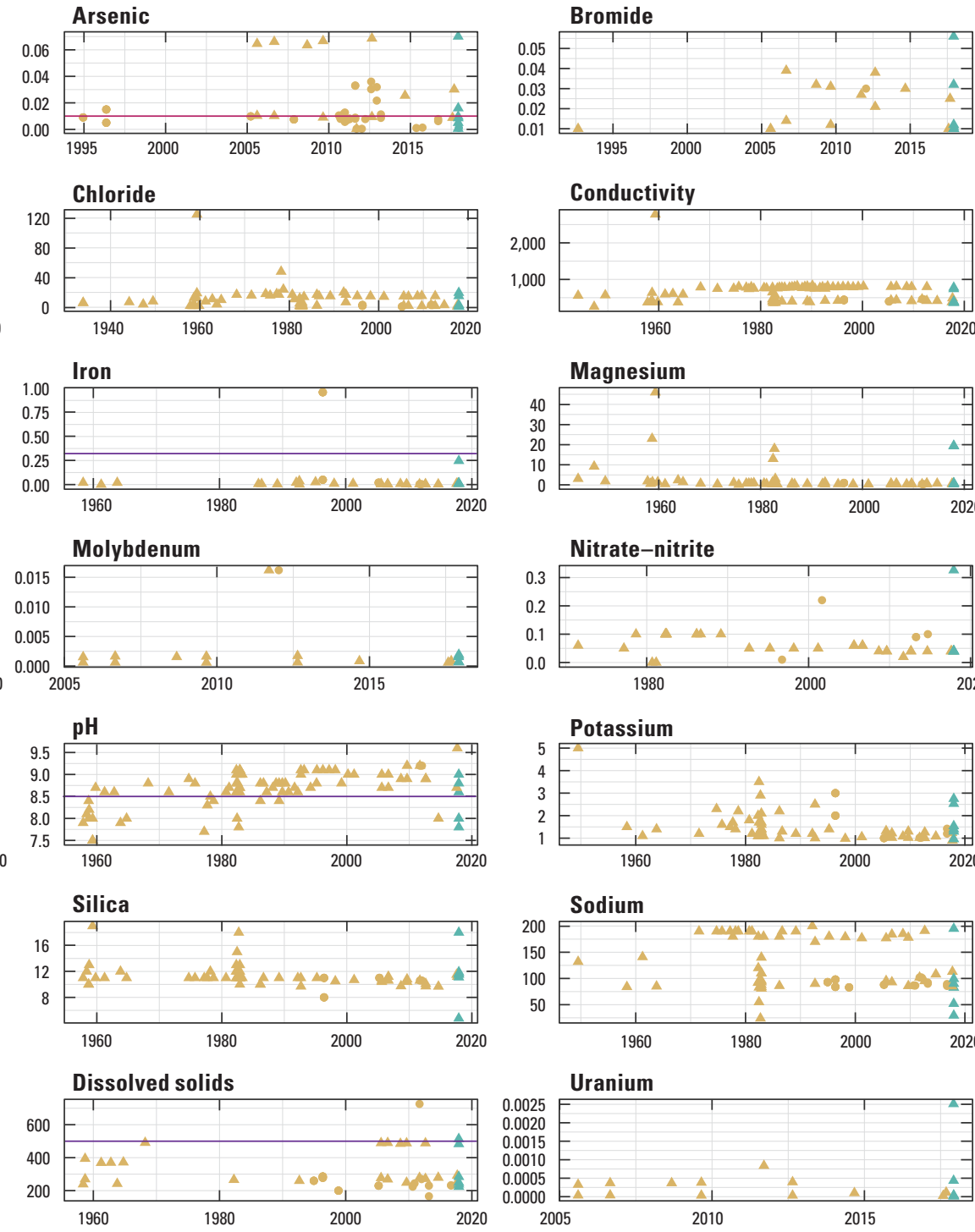

EXPLANATION

Conductivity is reported in microsiemens per centimeter at 25 degrees Celsius.
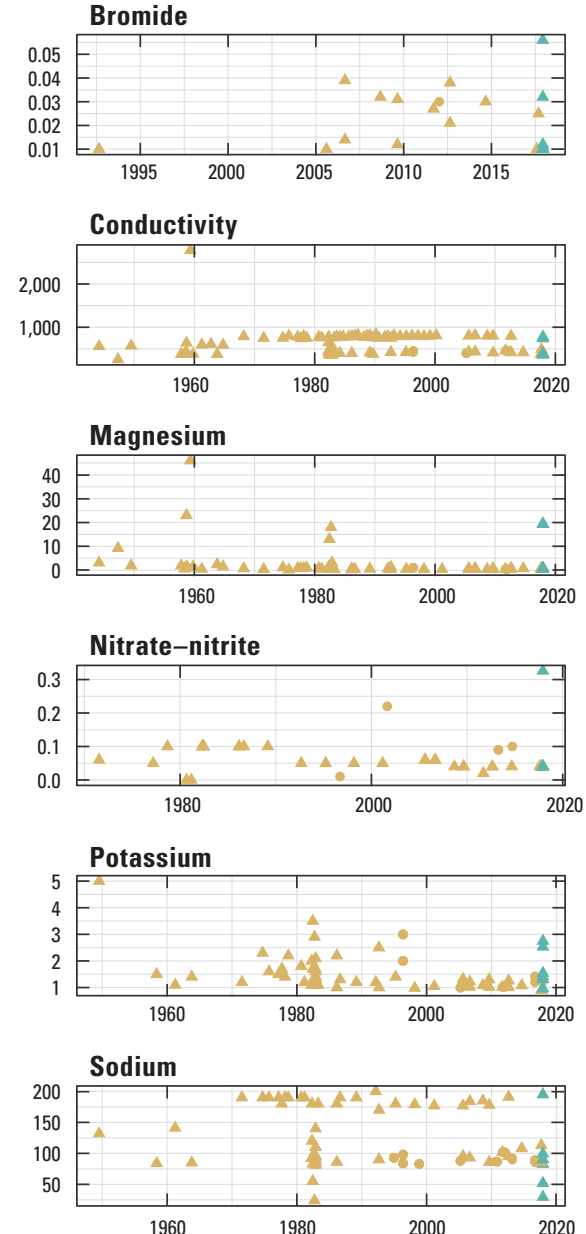

Samples collected for this study

Pre-existing samples

4 National Water Information System

- National Water Information System

- Safe Drinking Water Information System

Figure 3. Physical properties and concentrations of major ions, and selected trace elements and nutrients in water samples collected in and around Bluff, Utah, for this study compared to pre-existing data. 

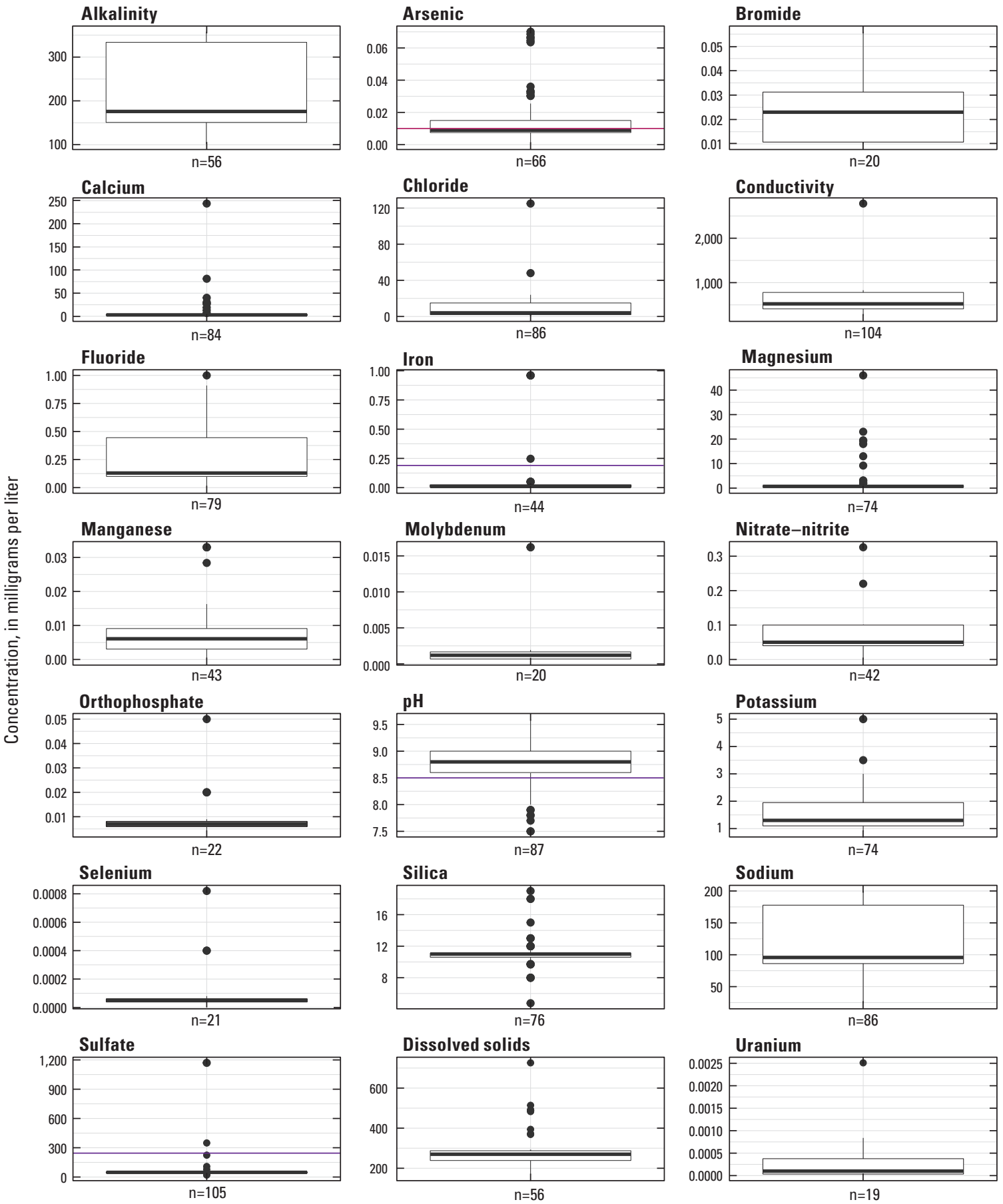

EXPLANATION

Conductivity is reported in microsiemens per centimeter at 25 degrees Celsius.

Drinking-water standard

- Maximum contaminant leve

- Secondary maximum contaminant level

n Number of samples

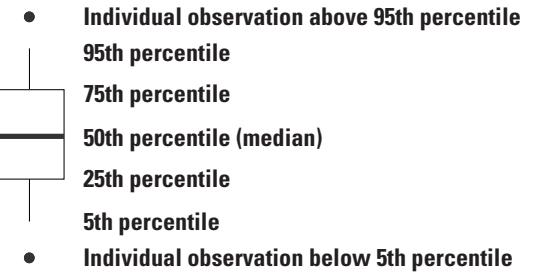

Figure 4. Statistical distribution of physical properties, major ions, and selected trace elements and nutrients in filtered and unfiltered water samples collected from wells, springs, and surface-water sites in and around Bluff, Utah. 
Table 4. Summary statistics for selected chemical constituents for which drinking-water standards have been established from water samples collected in and around Bluff, Utah, compared to drinking-water standards.

[Results are reported in milligrams per liter unless otherwise noted. Maximum contaminant level (MCL) and secondary maximum contaminant level (SMCL) from U.S. Environmental Protection Agency (2018). Abbreviations: pCi/L, picocurie per liter; NA, not applicable; <, less than]

\begin{tabular}{|c|c|c|c|c|c|c|c|c|c|}
\hline Analyte & $\begin{array}{l}\text { Minimum } \\
\text { concentration, } \\
\text { milligrams } \\
\text { per liter }\end{array}$ & $\begin{array}{l}\text { Maximum } \\
\text { concentration, } \\
\text { milligrams } \\
\text { per liter }\end{array}$ & $\begin{array}{l}\text { Median } \\
\text { concentration, } \\
\text { milligrams } \\
\text { per liter }\end{array}$ & $\begin{array}{c}\text { Mean } \\
\text { concentration, } \\
\text { milligrams } \\
\text { per liter }\end{array}$ & $\begin{array}{c}\text { Standard } \\
\text { deviation, } \\
\text { milligrams } \\
\text { per liter }\end{array}$ & $\begin{array}{c}\text { Number of } \\
\text { samples }\end{array}$ & $\begin{array}{c}\text { Maximum } \\
\text { contaminant } \\
\text { level, milligrams } \\
\text { per liter }\end{array}$ & $\begin{array}{c}\text { Secondary } \\
\text { maximum } \\
\text { contaminant level, } \\
\text { milligrams per liter }\end{array}$ & $\begin{array}{c}\text { Regulatory } \\
\text { exceedance } \\
\text { type }\end{array}$ \\
\hline Antimony & 0.00100 & 0.00370 & 0.00100 & 0.00190 & 0.00156 & 3 & 0.006 & NA & None \\
\hline Arsenic & 0.0005 & 0.0701 & 0.009 & 0.0160 & 0.0181 & 66 & 0.01 & NA & MCL \\
\hline Barium & 0.0040 & 0.0300 & 0.0200 & 0.0183 & 0.0092 & 16 & 2 & NA & None \\
\hline Bromate & 0.03 & 0.03 & 0.03 & 0.03 & NA & 1 & 0.01 & NA & MCL \\
\hline Cadmium & $<0.0006$ & 0.0010 & 0.0006 & 0.0006 & 0.0005 & 4 & 0.005 & NA & None \\
\hline Chloride & 0.80 & 125 & 4.00 & 9.41 & 14.84 & 86 & NA & 250 & None \\
\hline Chromium & $<0.0006$ & 0.0100 & 0.0032 & 0.0053 & 0.0044 & 5 & 0.1 & NA & None \\
\hline Copper & 0.0009 & 0.0109 & 0.0030 & 0.0039 & 0.0032 & 7 & 1.3 & 1 & None \\
\hline Cyanide & 0.003 & 0.003 & 0.003 & 0.003 & NA & 1 & 0.2 & NA & None \\
\hline Dissolved solids & 166 & 726 & 270 & 303 & 107 & 56 & NA & 500 & SMCL \\
\hline Fluoride & $<0.01$ & 1.00 & 0.13 & 0.28 & 0.25 & 79 & NA & 2 & None \\
\hline Foaming agents (surfactants) & 0.02 & 0.02 & 0.02 & 0.02 & 0 & 3 & NA & 0.5 & None \\
\hline Iron & $<0.01$ & 0.96 & 0.01 & 0.11 & 0.28 & 44 & NA & 0.3 & SMCL \\
\hline Lead & 0.00011 & 0.01040 & 0.00041 & 0.00234 & 0.00451 & 5 & 0.015 & NA & None \\
\hline Manganese & $<0.0004$ & 0.0330 & 0.0061 & 0.0089 & 0.0092 & 43 & NA & 0.05 & None \\
\hline Nitrate-Nitrite & $<0.04$ & 0.33 & 0.05 & 0.07 & 0.06 & 42 & 10 & NA & None \\
\hline p-Dichlorobenzene & $<0.0001$ & 0.0047 & 0.0047 & 0.0035 & 0.0023 & 4 & 0.075 & NA & None \\
\hline pH (standard units) & 7.5 & 9.6 & 8.8 & 8.7 & 0.4 & 87 & NA & 8.5 & SMCL \\
\hline Radium-228 (pCi/L) & 0.4 & 0.9 & 0.7 & 0.7 & 0.3 & 8 & 5 & NA & None \\
\hline Selenium & $<0.00005$ & 0.00082 & 0.00005 & 0.00012 & 0.00019 & 21 & 0.05 & NA & None \\
\hline Sulfate & 20.0 & 1,170 & 48.0 & 61.5 & 115 & 105 & NA & 250 & SMCL \\
\hline Thallium & 0.00002 & 0.00100 & 0.00100 & 0.00076 & 0.00040 & 6 & 0.002 & NA & None \\
\hline Toluene & $<0.0002$ & 0.0011 & 0.0011 & 0.0009 & 0.0005 & 5 & 1 & NA & None \\
\hline Uranium & $<0.00003$ & 0.00251 & 0.00010 & 0.00032 & 0.00057 & 19 & 0.03 & NA & None \\
\hline Zinc & 0.006 & 0.082 & 0.007 & 0.027 & 0.035 & 11 & NA & 5 & None \\
\hline
\end{tabular}




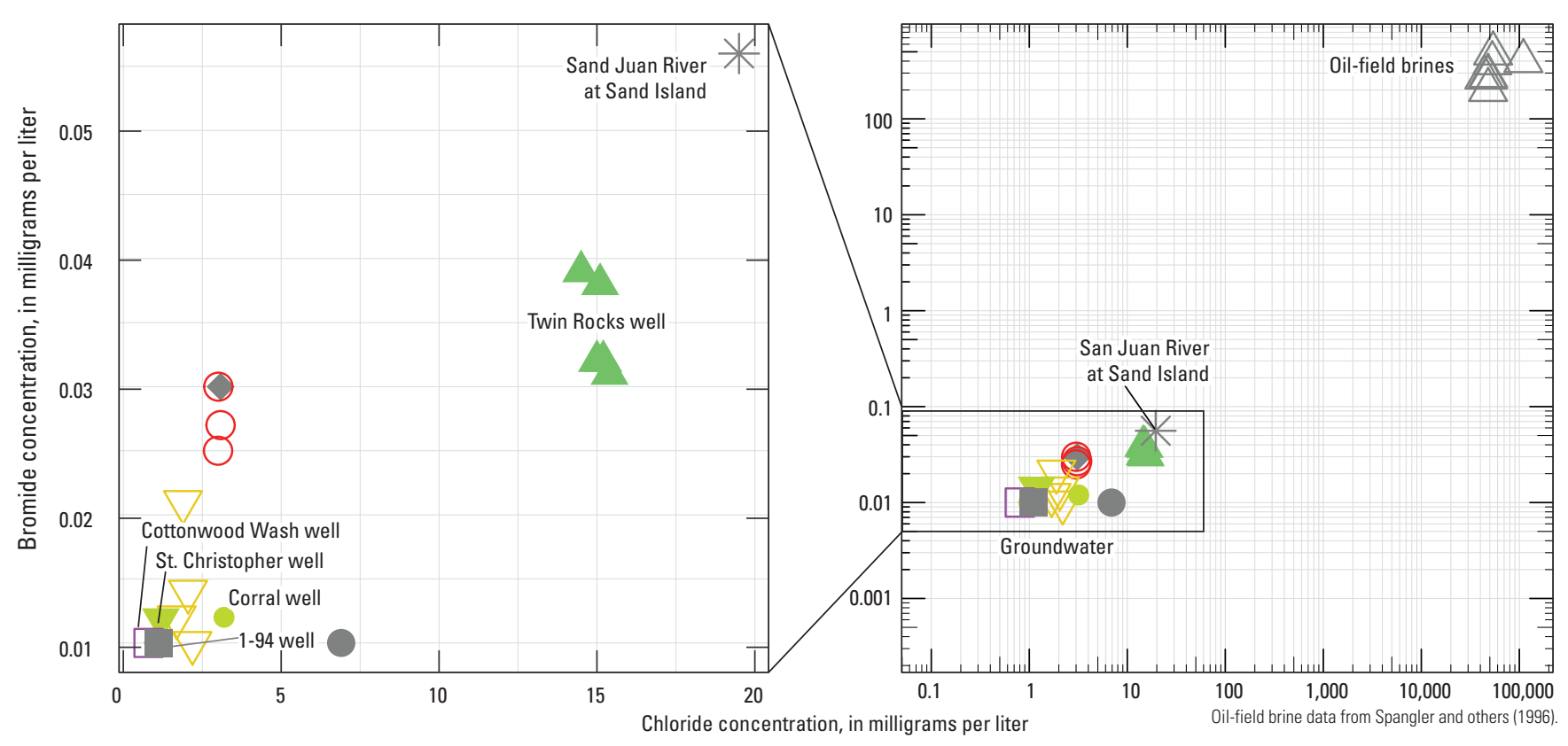

\section{EXPLANATION}

\begin{tabular}{|c|c|c|}
\hline Well depth, in feet & \multicolumn{2}{|c|}{$\begin{array}{l}\text { Site (15-digit number refers to U.S. Geological Survey site numbe } \\
\text { Grey symbols indicate well depth is undetermined. }\end{array}$} \\
\hline 1,250 & * 371542109364401 & A 371716109325501 \\
\hline 1,000 & ○ 371545109364402 & 371747109275301 \\
\hline 750 & $\nabla 371657109331901$ & $\square 372408109312301$ \\
\hline 500 & $\nabla 371707109304301$ & $\triangle$ Oil-field brine \\
\hline Unknown depth & $\begin{array}{l}\text { - } 371707109323201 \\
\\
\end{array} 371711109335401$ & Sand Island well \\
\hline
\end{tabular}

Figure 5. Bromide and chloride concentrations in water samples collected from the principal bedrock aquifers, San Juan River, and the adjacent alluvial aquifer in and around Bluff, Utah, between 1992 and 2017, compared to bromide and chloride concentrations in oil-field brines from the Aneth Oil Field.

\section{Dissolved Hydrocarbon Gases}

Water samples collected during this study from bedrock and alluvial aquifers, and from the San Juan River had concentrations of dissolved hydrocarbon gases close to or below the analytical detection limit. Dissolved hydrocarbons, produced through fermentation, carbon dioxide reduction metabolic pathways, or thermogenic processes, can be detected in most anoxic aquifers (Gorody, 2012). The mole percentage of dissolved gas and gas concentrations is shown in table 5. Methane was detected in samples collected from all sites. The minimum methane concentration was $0.00042 \mathrm{mg} / \mathrm{L}$ (Corral well, USGS site number 371707109323201), and the maximum concentration was $0.0089 \mathrm{mg} / \mathrm{L}$ (Twin Rocks well, USGS site number 371716109325501). The methane concentrations in water from the Twin Rocks and 1-94 (USGS site number 371711109335401 ) wells (about $0.001 \mathrm{mg} / \mathrm{L}$ ) were an order of magnitude greater than the concentrations in water from the other wells (about $0.0001 \mathrm{mg} / \mathrm{L}$ ). After averaging the methane concentrations of the replicate samples collected at the St. Christopher well (USGS site number 371707109304301), the median value for all sites was $0.00074 \mathrm{mg} / \mathrm{L}$. The methane concentrations in these samples were too low for carbon-13 and hydrogen isotope ratio analysis. Concentrations of ethane and propane in all Bluff water samples were below the detection limit of $0.0002 \mathrm{mg} / \mathrm{L}$ for both gases.

The San Juan River sample had the highest dissolved oxygen concentration, as expected for a surface-water sample compared to groundwater samples. The pump in the Corral well was running while sampling was taking place, which could explain the elevated dissolved oxygen relative to that in other samples. 
Table 5. Composition of dissolved gases in water samples collected from selected wells in the principal bedrock aquifers and from the San Juan River in and around Bluff, Utah, December 4 to 7, 2017.

$[\mathrm{mm} / \mathrm{dd} / \mathrm{yyyy}, \mathrm{month} /$ day/year; $<$, less than $]$

\begin{tabular}{|c|c|c|c|c|c|c|c|c|c|c|c|}
\hline \multirow[t]{2}{*}{ Site name } & Site number & \multirow[t]{2}{*}{$\begin{array}{c}\text { Date } \\
\text { (mm/dd/yyyy) }\end{array}$} & Argon & $\begin{array}{l}\text { Carbon } \\
\text { dioxide }\end{array}$ & $\begin{array}{l}\text { Carbon } \\
\text { monoxide }\end{array}$ & Dinitrogen & Hydrogen & Oxygen & Prop & $\begin{array}{r}\text { C6 } \\
\text { mole } \\
\text { hy }\end{array}$ & $\begin{array}{l}\text { and higher- } \\
\text { cular-weight } \\
\text { drocarbons }\end{array}$ \\
\hline & \multicolumn{10}{|c|}{ mole percent of dissolved gases } & \\
\hline Corral well & 371707109323201 & $12 / 06 / 2017$ & 1.47 & 0.49 & $<0.010$ & 84.51 & $<0.01$ & 13.53 & $<0$. & 001 & $<0.0001$ \\
\hline Cottonwood Wash well & 372408109312301 & $12 / 07 / 2017$ & 1.82 & 1.66 & $<0.010$ & 92.16 & $<0.01$ & 4.36 & $<0$ & 001 & $<0.0001$ \\
\hline 1-94 well & 371711109335401 & $12 / 06 / 2017$ & 1.84 & 0.2 & $<0.010$ & 94.31 & $<0.01$ & 3.61 & $<0$ & 001 & $<0.0001$ \\
\hline San Juan River at Sand Island & 371542109364401 & $12 / 04 / 2017$ & 1.49 & 0.47 & $<0.010$ & 65.86 & $<0.01$ & 32.18 & $<0$ & 001 & $<0.0001$ \\
\hline St. Christopher well & 371707109304301 & $12 / 05 / 2017$ & 1.81 & 0.28 & $<0.010$ & 92.79 & $<0.01$ & 5.12 & $<0$. & 001 & $<0.0001$ \\
\hline St. Christopher replicate & 371707109304301 & $12 / 05 / 2017$ & 1.86 & 0.29 & $<0.010$ & 92.98 & $<0.01$ & 4.87 & $<0$ & 001 & $<0.0001$ \\
\hline Twin Rocks well & 371716109325501 & $12 / 05 / 2017$ & 1.72 & 0.19 & $<0.010$ & 91.45 & $<0.01$ & 6.59 & $<0$. & 001 & $<0.0001$ \\
\hline \multirow[t]{2}{*}{ Site name } & \multirow[t]{2}{*}{ Site number } & \multirow{2}{*}{$\begin{array}{c}\text { Date } \\
\text { (mm/dd/yyyy) }\end{array}$} & n-Butane & Ethane & Ethene & Methane & $\begin{array}{c}\text { 2-Methylbutane } \\
\text { (isopentane) }\end{array}$ & $\begin{array}{r}\text { 2-Methylprop } \\
\text { (isobutane) }\end{array}$ & ) & n-Pentane & Propane \\
\hline & & & \multicolumn{9}{|c|}{ recoverable, mole percent of dissolved gases } \\
\hline Corral well & 371707109323201 & $12 / 06 / 2017$ & $<0.0001$ & $<0.0001$ & $<0.0001$ & 0.0012 & $<0.0001$ & $<0.0001$ & & $<0.0001$ & $<0.0001$ \\
\hline Cottonwood Wash well & 372408109312301 & $12 / 07 / 2017$ & $<0.0001$ & $<0.0001$ & $<0.0001$ & 0.0027 & $<0.0001$ & $<0.0001$ & & $<0.0001$ & $<0.0001$ \\
\hline 1-94 well & 371711109335401 & $12 / 06 / 2017$ & $<0.0001$ & $<0.0001$ & $<0.0001$ & 0.0417 & $<0.0001$ & $<0.0001$ & & $<0.0001$ & $<0.0001$ \\
\hline San Juan River at Sand Island & 371542109364401 & $12 / 04 / 2017$ & $<0.0001$ & $<0.0001$ & $<0.0001$ & 0.004 & $<0.0001$ & $<0.0001$ & & $<0.0001$ & $<0.0001$ \\
\hline St. Christopher well & 371707109304301 & $12 / 05 / 2017$ & $<0.0001$ & $<0.0001$ & $<0.0001$ & 0.0035 & $<0.0001$ & $<0.0001$ & & $<0.0001$ & $<0.0001$ \\
\hline St. Christopher replicate & 371707109304301 & $12 / 05 / 2017$ & $<0.0001$ & $<0.0001$ & $<0.0001$ & 0.0032 & $<0.0001$ & $<0.0001$ & & $<0.0001$ & $<0.0001$ \\
\hline Twin Rocks well & 371716109325501 & $12 / 05 / 2017$ & $<0.0001$ & $<0.0001$ & $<0.0001$ & 0.049 & $<0.0001$ & $<0.0001$ & & $<0.0001$ & $<0.0001$ \\
\hline \multirow{2}{*}{ Site name } & \multirow{2}{*}{ Site number } & \multirow{2}{*}{$\begin{array}{c}\text { Date } \\
\text { (mm/dd/yyyy) }\end{array}$} & Ethane & \multicolumn{3}{|c|}{ Propane } & & & & & \\
\hline & & & \multicolumn{4}{|c|}{ recoverable, milligrams per liter } & & & & & \\
\hline Corral well & 371707109323201 & $12 / 06 / 2017$ & $<0.0002$ & 0.00042 & $<0$ & 0002 & & & & & \\
\hline Cottonwood Wash well & 372408109312301 & $12 / 07 / 2017$ & $<0.0002$ & 0.00049 & $<0$ & 0002 & & & & & \\
\hline 1-94 well & 371711109335401 & $12 / 06 / 2017$ & $<0.0002$ & 0.0078 & $<0$ & 0002 & & & & & \\
\hline San Juan River at Sand Island & 371542109364401 & $12 / 04 / 2017$ & $<0.0002$ & 0.00085 & $<0$ & 0003 & & & & & \\
\hline St. Christopher well & 371707109304301 & $12 / 05 / 2017$ & $<0.0002$ & 0.00067 & $<0$ & 0002 & & & & & \\
\hline St. Christopher replicate & 371707109304301 & $12 / 05 / 2017$ & $<0.0002$ & 0.0006 & $<0$ & 0002 & & & & & \\
\hline Twin Rocks well & 371716109325501 & $12 / 05 / 2017$ & $<0.0002$ & 0.0089 & $<0$ & 0002 & & & & & \\
\hline
\end{tabular}




\section{Hydrogen and Oxygen Isotope Ratios}

The hydrogen and oxygen isotope ratios of groundwater samples and the sample collected from the San Juan River ranged from -118.06 to -89.61 permil and from -16.04 to -12.1 permil, respectively (table 6$)$. The hydrogen $\left(\delta^{2} \mathrm{H}\right)$ and oxygen $\left(\delta^{18} \mathrm{O}\right)$ isotope values for groundwater and surfacewater samples fell within the normal range of meteoric waters (fig. 6); samples generally plot along or slightly above both the Global and Salt Lake Valley meteoric water lines (Craig, 1961; Jameel and others, 2016). The isotope values of groundwater samples were similar and decreased with depth, whereas the San Juan River sample values were higher. The difference between the $\delta^{18} \mathrm{O}$ and $\delta^{2} \mathrm{H}$ values of groundwater and surfacewater samples reflects different precipitation, recharge conditions, and mixing patterns. The lower isotope values of the deeper groundwater samples were similar to isotope values of snow samples collected in the Abajo Mountains, approximately $40 \mathrm{mi}$ north of Bluff (Spangler and others, 1996), indicating that recharge to the deeper principal bedrock aquifers was in or near the Abajo Mountains or that recharge occurred under cooler or higher-altitude conditions. The higher $\delta^{18} \mathrm{O}$ and $\delta^{2} \mathrm{H}$ values of shallower groundwater samples indicate warmer or lower-altitude recharge. Downward movement of surface water with higher $\delta^{18} \mathrm{O}$ and $\delta^{2} \mathrm{H}$ values, which could also cause the $\delta^{18} \mathrm{O}$ and $\delta^{2} \mathrm{H}$ values in shallower aquifers to increase, is not likely because hydraulic gradients and the presence of flowing wells near the San Juan River indicate that groundwater moves upward and discharges around the San Juan River. The $\delta^{18} \mathrm{O}$ and $\delta^{2} \mathrm{H}$ values of the San Juan River reflect either discharge of groundwater that recharged under warmer, lower-altitude conditions and (or) mixing of precipitation and runoff of precipitation occurring in Bluff, Silverton, and Cortez.

The isotopic composition of oil-field brines is distinct from water in the principal bedrock aquifers, indicating that mixing of the water in these aquifers, which supply drinking water, with oil-field brines potentially can be identified (fig. 6). The hydrogen and oxygen isotope ratios of oil-field brine samples ranged from -79.0 to -42.0 permil and from -7.58 to 2.19 permil, respectively (Spangler and others, 1996). Changes in the isotopic composition of principal bedrock aquifer water along a mixing line with brine water could indicate that water in the principal bedrock aquifers has mixed with oil-field brine and that drinking water for public supply might have been affected.

Table 6. Hydrogen and oxygen isotope ratios of water samples collected from selected wells in the principal bedrock aquifers and from the San Juan River in and around Bluff, Utah, December 4 to 7, 2017.

$\left[\delta^{18} \mathrm{O}\right.$, ratio of ratio of oxygen- 18 to oxygen- 16 in sample to ratio of oxygen- 18 to oxygen- 16 in reference material $-1 \times 1,000 ; \delta^{2} \mathrm{H}$, ratio of ratio of hydrogen-2 to hydrogen-1 in sample to ratio of hydrogen-2 to hydrogen-1 in reference material -1 x 1,000; permil, per thousand. Abbreviation: mm/dd/yyyy, month/day/ year]

\begin{tabular}{|c|c|c|c|c|}
\hline Site name & Site number & $\begin{array}{c}\text { Date } \\
\text { (mm/dd/yyyy) }\end{array}$ & $\begin{array}{c}\delta^{18} 0, \\
\text { in permil }\end{array}$ & $\begin{array}{c}\delta^{2} \mathrm{H}, \\
\text { in permil }\end{array}$ \\
\hline Corral well & 371707109323201 & $12 / 06 / 2017$ & -112.63 & -15.44 \\
\hline 1-94 well & 371711109335401 & $12 / 06 / 2017$ & -113.47 & -15.58 \\
\hline San Juan River at Sand Island & 371542109364401 & $12 / 04 / 2017$ & -89.61 & -12.1 \\
\hline Twin Rocks well & 371716109325501 & $12 / 05 / 2017$ & -110.2 & -15.05 \\
\hline
\end{tabular}




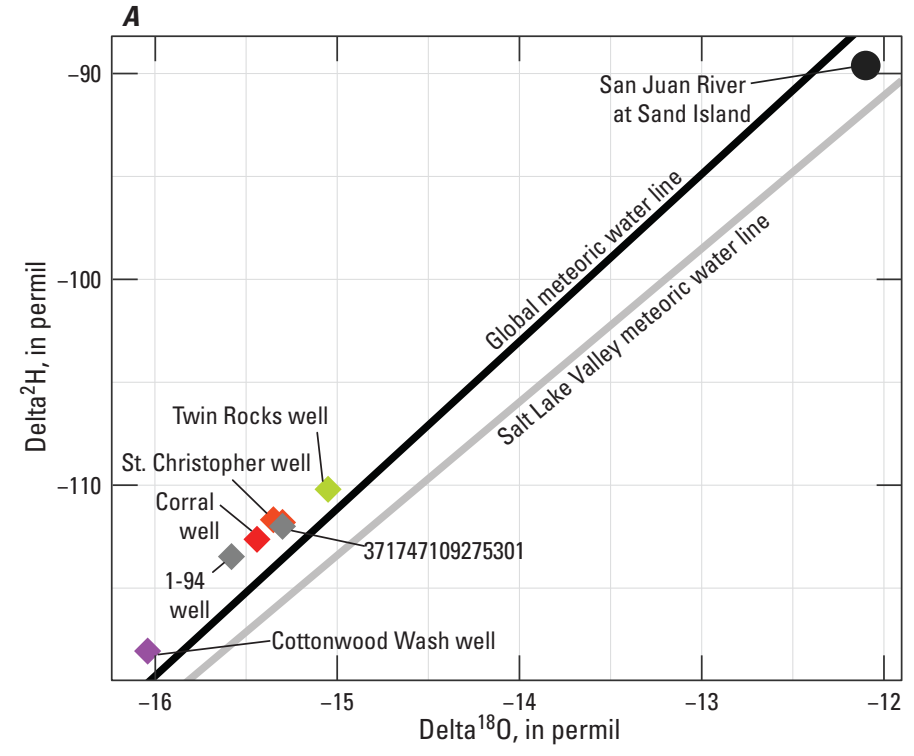

\section{EXPLANATION}

\begin{tabular}{|c|c|}
\hline Well depth, in feet & $\begin{array}{l}\text { Sample type-Large symbol indicates sample } \\
\text { collected for this study; small symbol indicates }\end{array}$ \\
\hline 1,200 & pre-existing sample; color indicates well depth \\
\hline 1,000 & $\begin{array}{l}\text { - Groundwater } \\
\text { - Pond }\end{array}$ \\
\hline 800 & $\$$ Oil-field brine \\
\hline $\begin{array}{l}600 \\
\text { Unknown depth }\end{array}$ & - Precipitation \\
\hline $\begin{array}{l}\text { digit number refers to } \\
\text { Geological Survey site number }\end{array}$ & - Stream \\
\hline
\end{tabular}

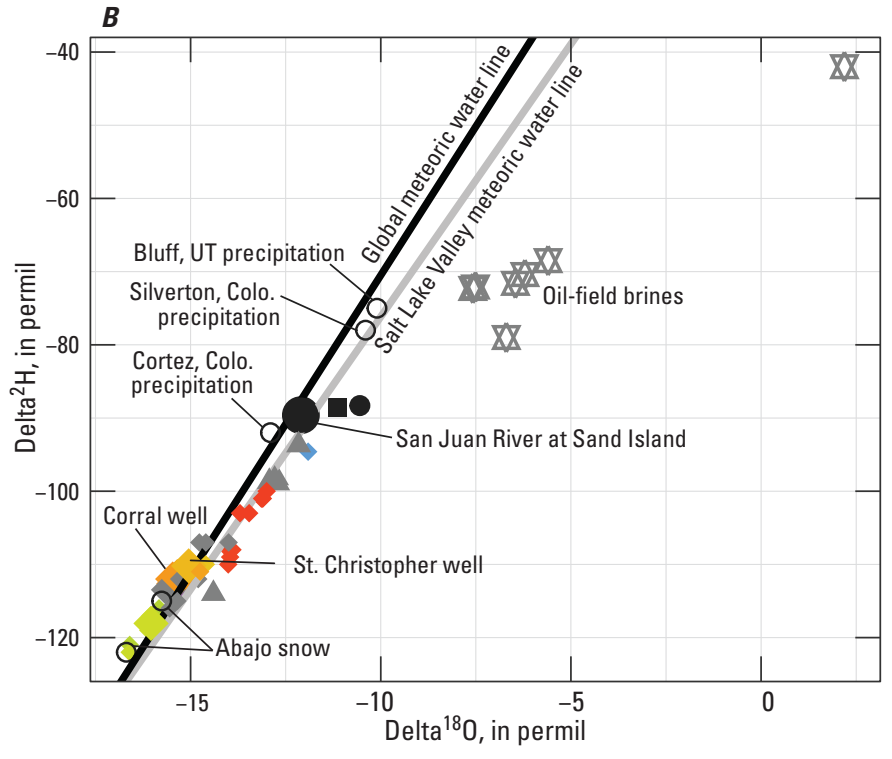

Oil-field brine data from Spangler and others (1996). Salt Lake Valley meteoric water line from Jameel and others (2016).

\section{EXPLANATION}

Well depth, in feet Sample type-Large symbol indicates sample collected for this study; small symbol indicates pre-existing sample; color indicates well depth

- Groundwater

- Pond

\$ Oil-field brine

- Precipitation

- Spring

- Stream

Figure 6. A, The isotopic composition of groundwater and surface-water samples collected in and around Bluff, Utah, in relation to the global $\left(\delta^{2} \mathrm{H}=8 \times \delta^{18} 0+10\right)$ and Salt Lake Valley $\left(\delta^{2} \mathrm{H}=7.45 \times \delta^{18} 0-1.66\right)$ meteoric water lines, and $B$, the isotopic composition of groundwater, surface-water, and precipitation samples, and oil-field brines in relation to the global and Salt Lake Valley meteoric water lines. 


\section{Groundwater Flow Direction, Travel Times, and Age}

Groundwater in the principal bedrock aquifers generally moves from north to south based on water-level measurements made between 2012 and 2017 in the study area. The proposed production-well boreholes are upgradient from the town of Bluff and the San Juan River (fig. 7). Thus, contaminants originating at either of the proposed production wells have the potential to move toward the San Juan River and Bluff. The overall pattern of the potentiometric surface is similar to the generalized direction of groundwater movement shown in Spangler and others (1996).

The mean hydraulic gradient in the area covered by the potentiometric surface contour lines is 0.006 . For effective porosities between 0.1 and 0.3 , the average linear velocity is between 7 and 2 feet per year, respectively. The distance along an idealized flow path from the southern proposed production well to the Corral well is approximately $31,400 \mathrm{ft}$, and the distance from the northern proposed production well is approximately $44,000 \mathrm{ft}$. Using these distances, effective porosities, and average linear velocities, the estimated groundwater travel times from the southern production well ranged from 4,214 to 12,642 years, and travel times from the northern production well ranged from 5,905 to 17,716 years. This method of calculating travel times is simplistic, and a more precise estimate could be obtained by developing a numerical groundwater flow model. This calculation does not account for any chemical reactions and assumes that the hydraulic-head distribution in the study area remains constant during this time. Chemical reactions, particularly for petroleum-based constituents, tend to consume the compounds and can increase travel times. Changes in pumping at wells could also alter the hydraulic gradient, which would affect travel times. For example, doubling the hydraulic gradient from 0.006 to 0.012 (by pumping enough water in Bluff to reduce the hydraulic head by approximately $190 \mathrm{ft}$ ) would reduce travel times by half to between 2,107 and 6,321 years from the southern production well. Groundwater flow along fractures could also substantially reduce travel times. The distribution of travel times varies based on site-specific aquifer properties, and the travel times estimated using the simple equation applied in this report have substantial uncertainties. This method, however, gives a general first-order estimate and indicates that contaminants originating at the proposed production wells would not immediately affect the water quality of Bluff's drinking-water supply wells.

The ${ }^{14} \mathrm{C}$ apparent age of water sampled from the Corral well (USGS site number 371707109323201) in 2017 indicates that recharge to the aquifer that provides water to the well could have occurred during the Pleistocene. The ${ }^{14} \mathrm{C}$ age using the Tamers adjustment model is 37,946 years since recharge. The ${ }^{14} \mathrm{C}$ age using the Fontes and Garnier adjustment model is 33,231 to 35,957 years, using soil $\mathrm{CO}_{2} \delta^{13} \mathrm{C}$ values of -2 or 2 permil, respectively. These ages are consistent with recharge occurring near the Abajo Mountains and moving through the subsurface at the estimated average linear velocities and effective porosities calculated previously. These ages indicate that a substantial amount of time would be required for drinking-water quality in Bluff to be affected by contaminants in surface or groundwaters several miles away; however, these ages, and the low rates of precipitation in the area, also highlight the vulnerability of groundwater in the area to depletion if pumping outpaces recharge.

Groundwater can transport contaminants in the direction dictated by the hydraulic gradient. Within 10 to $15 \mathrm{mi}$ of the San Juan River, Spangler and others (1996) identified upward hydraulic gradients, indicating vertical movement of groundwater from the Navajo aquifer to the Morrison aquifer and San Juan River. Downward vertical hydraulic gradients also indicate that movement of water from the Morrison aquifer to the Navajo aquifer is possible. Low-permeability confining layers overlying deeper aquifers and upward hydraulic gradients close to the San Juan River can impede the downward movement of contaminants from the surface. Thus, the potential for water-quality degradation in deeper aquifers from surface spills is greater in areas of downward hydraulic gradients. 


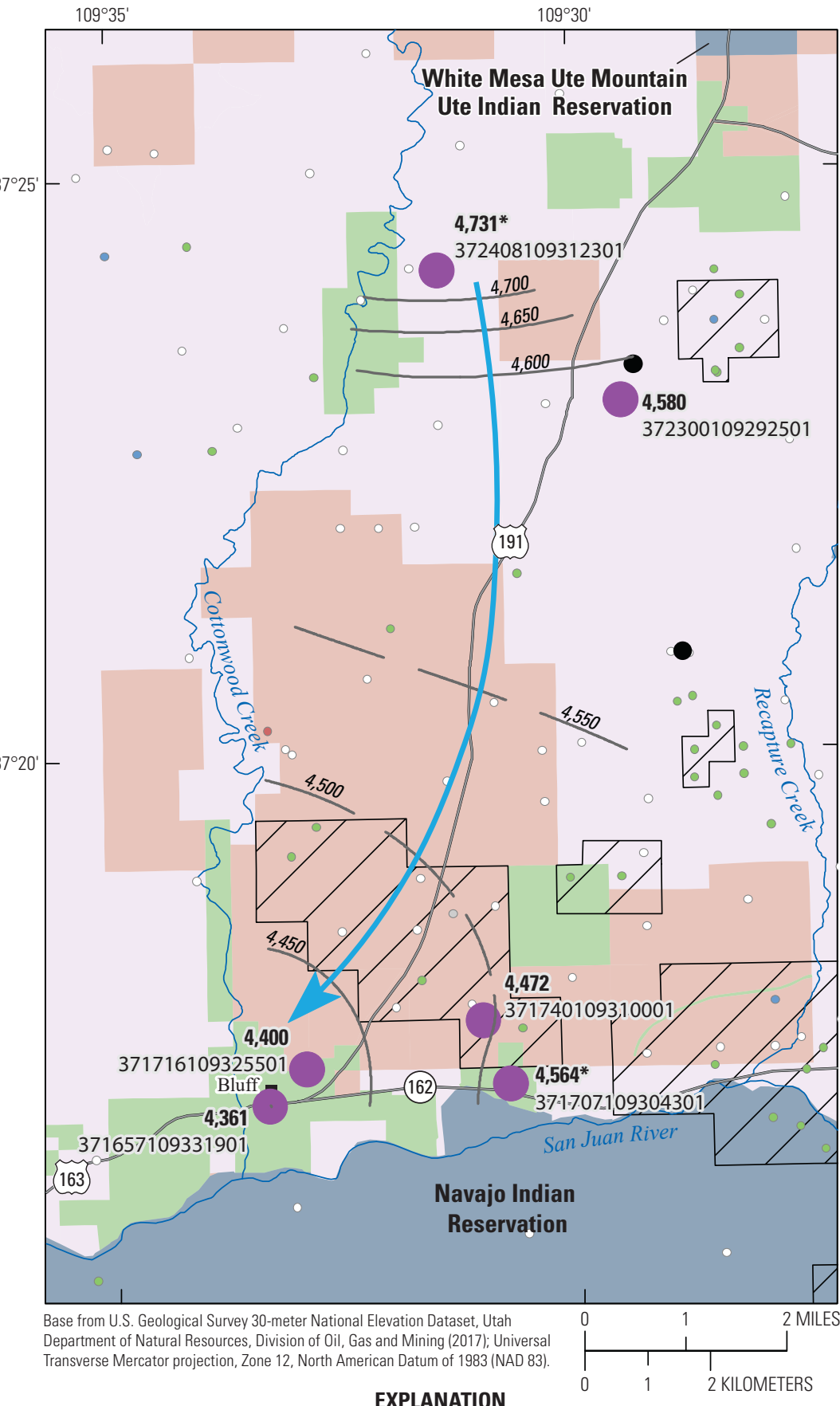

Oil and gas field

Land ownership

$\begin{array}{ll}\text { Federal } & \text { State } \\ \text { Private } & \text { Tribal }\end{array}$

EXPLANATION

Proposed production well

\section{4,361}

371657109331901

Well and water-table altitude, in feet-

15-digit number refers to U.S. Geological Survey

site number. * minimum water-level altitude
Existing production-related wells Existing production wells and fields from Utah Department of Natural Resources, Division of Oil, Gas and Mining (2017).

$\circ$ Dry

- Oil

- Gas

- Water disposal

Shows approximate a of water-level surface. Dashed where less certain.

Arrow shows general direction

of groundwater movement

Figure 7. Potentiometric surface contours from water-level measurements made between 2012 and 2017 at wells in and around Bluff, Utah. 


\section{Conclusions and Future Monitoring}

The drinking-water supply from bedrock aquifers for the town of Bluff, Utah, is generally of good quality. Overall, concentrations of most constituents analyzed were low (below EPA drinking-water standards), making them sensitive indicators of changes to the groundwater system, potentially resulting from human activities upgradient from public-supply wells. The concentrations of ethane and propane in water from wells in the principal bedrock aquifers were below the analytical detection limit. Increases in concentrations of ethane or propane, therefore, might prove to be useful indicators of hydrocarbon gases migrating into the principal bedrock aquifers. Further, increases in methane concentrations to the level that isotopic analysis of methane carbon and hydrogen isotope ratios is possible could yield insights into hydrocarbon sources and processes in the aquifers. Changes in concentrations of dissolved solids, bromide and chloride, and oxygen and hydrogen isotope ratios could also prove to be indicators of mixing with produced waters or fluids in this area as has been shown in other areas.

To determine the source of potential contaminants related to hydrocarbon extraction, data on potential sources are required. Some data on oil-field brine chemistry from the Aneth Oil Field (bromide and chloride concentrations, dissolved-solids concentrations, major anions, and stable isotopes) were collected in the early 1990s; however, more recent and comprehensive data (for example, hydrocarbon concentrations or isotopic compositions) and data for other sources (for example, hydraulic fracturing fluids) do not exist or are not publicly available. Nonetheless, baseline waterquality data compiled during this study in conjunction with data collected previously, can now be used as a tool to help determine and evaluate potential changes in, and sources of, water-quality degradation from man-made activities including those that occur in oil-field operations.

Groundwater in the study area generally moves toward Bluff and the San Juan River. Potential contaminants in groundwater near the proposed production wells could take thousands of years to arrive at water-supply wells in Bluff if the hydrologic conditions remain constant, and increased groundwater withdrawals could reduce travel time in the vicinity of the wells. Water-quality degradation from surface activities near Bluff, such as transport or storage of produced waters or hydraulic fracturing fluids, could affect the town's water supply more quickly, particularly in areas where downward vertical hydraulic gradients exist. Numerical modeling would inform contaminant transport scenarios in greater detail.

\section{References Cited}

Avery, C., 1986, Bedrock aquifers of eastern San Juan County, Utah: U.S. Geological Survey Technical Publication 86, $114 \mathrm{p}$.

Bowen, G.J., and Revenaugh, J., 2003, Interpolating the isotopic composition of modern meteoric precipitation: Water Resources Research, v. 39, no. 10, p. 1-13, https://doi.org/10.1029/2003WR002086.

Bowen, G.J., Wassenaar, L.I., and Hobson, K.A., 2005, Global application of stable hydrogen and oxygen isotopes to wildlife forensics: Oecologia, v. 143, no. 3, p. 337-348, https://doi.org/10.1007/s00442-004-1813-y.

Bowen, G.J., and Wilkinson, B., 2002, Spatial distribution of $\delta^{18} \mathrm{O}$ in meteoric precipitation: Geological Society of America Bulletin, v. 30, no. 4, p. 315-318.

Breen, K.J., Angelo, C.G., Masters, R.W., and Sedam, A.C., 1985, Chemical and isotopic characteristics of brines from three oil- and gas-producing sandstones in eastern Ohio, with applications to the geochemical tracing of brine sources (ver. 1.1, September 18, 2013): U.S. Geological Survey Water-Resources Investigations Report 84-4314, $58 \mathrm{p}$.

Burden, C.B., and others, 2016, Groundwater conditions in Utah, spring of 2016: Utah Department of Natural Resources Cooperative Investigations Report No. 57, 118 p.

Cerling, T.E., Solomon, D.K., Quade, J., and Bowman, J.R., 1991, On the isotopic composition of carbon in soil carbon dioxide: Geochimica et Cosmochimica Acta, v. 55, no. 11, p. 3403-3405, https://doi.org/10.1016/0016-7037(91)90498-T.

Clark, I.D., and Fritz, P., 1997, Environmental isotopes in hydrogeology: CRC Press, $328 \mathrm{p}$.

Coplen, T.B., 1994, Reporting of stable hydrogen, carbon, and oxygen isotopic abundances: Pure and Applied Chemistry, v. 66 , no. 2 , p. $273-276$.

Cordova, R.M., 1978, Ground-water conditions in the Navajo Sandstone in the central Virgin River basin, Utah: State of Utah Department of Natural Resources Technical Publication No. 61, 66 p., 3 pls.

Craig, H., 1961, Isotopic variations in meteoric waters: Science, v. 133, no. 3465, p. 1702-1703.

Eltschlager, K.K., Hawkins, J.W., Ehler, W.C., and Baldassare, F.J., 2001, Technical measures for the investigation and mitigation of fugitive methane hazards in areas of coal mining: Pittsburgh, Pa., U.S. Department of the Interior, Office of Surface Mining Reclamation and Enforcement, $129 \mathrm{p}$. 
Fontes, J.-C., and Garnier, J.-M., 1979, Determination of the initial ${ }^{14} \mathrm{C}$ activity of the total dissolved carbon-A review of the existing models and a new approach: Water Resources Research, v. 15, no. 2, p. 399-413, https://doi.org/10.1029/WR015i002p00399.

Gardner, P.M., and Heilweil, V.M., 2014, A multipletracer approach to understanding regional groundwater flow in the Snake Valley area of the eastern Great Basin, USA: Applied Geochemistry, v. 45, p. 33-49, https://doi.org/10.1016/j.apgeochem.2014.02.010.

Gorody, A.W., 2012, Factors affecting the variability of stray gas concentration and composition in groundwater: Environmental Geosciences, v. 19, no. 1, p. 17-31, https://doi.org/10.1306/eg.12081111013.

Heilweil, V.M., and Solomon, D.K., 2004, Millimeter- to kilometer-scale variations in vadose-zone bedrock solutesImplications for estimating recharge in arid settings, in Hogan, J., Phillips, F., and Scanlon, B., eds., Groundwater recharge in a desert environment - The southwestern United States: Washington D.C., American Geophysical Union, Water Science and Application Series, v. 9, p. 49-67.

Huffman, Jr., A.C., and Condon, S.M., 1993, Stratigraphy, structure, and paleogeography of Pennsylvanian and Permian rocks, San Juan Basin and adjacent areas, Utah, Colorado, Arizona, and New Mexico: U.S. Geological Survey Bulletin 1808-O, 44 p.

Humez, P., Mayer, B., Ing, J., Nightingale, M., Becker, V., Kingston, A., Akbilgic, O., and Taylor, S., 2016, Occurrence and origin of methane in groundwater in Alberta (Canada) - Gas geochemical and isotopic approaches: Science of the Total Environment, v. 541, p. 1253-1268, https://doi.org/10.1016/j.scitotenv.2015.09.055.

Jackson, R.E., Gorody, A.W., Mayer, B., Roy, J.W., Ryan, M.C., and Van Stempvoort, D.R., 2013, Groundwater protection and unconventional gas extraction-The critical need for field-based hydrogeological research: Groundwater, v. 51, no. 4, p. 488-510, https://doi.org/10.1111/gwat.12074.

Jameel, Y., Brewer, S., Good, S.P., Tipple, B.J., Ehleringer, J.R., and Bowen, G.J., 2016, Tap water isotope ratios reflect urban water system structure and dynamics across a semiarid metropolitan area: Water Resources Research, v. 52, no. 8, p. 5891-5910, https://doi.org/10.1002/2016WR019104.

Marston, T.M., and Heilweil, V.M., 2012, Numerical simulation of groundwater movement and managed aquifer recharge from Sand Hollow Reservoir, Hurricane Bench area, Washington County, Utah: U.S. Geological Survey Scientific Investigations Report 2012-5236, 34 p., https://doi.org/10.3133/sir20125236.
Naftz, D.L., and Spangler, L.E., 1994, Salinity increases in the Navajo aquifer in southeastern Utah: Journal of the American Water Resources Association, v. 30, no. 6, p. 1119-1135, https://doi.org/10.1111/j.1752-1688.1994.tb03357.x.

Orem, W., Tatu, C., Varonka, M., Lerch, H., Bates, A., Engle, M., Crosby, L., and McIntosh, J., 2014, Organic substances in produced and formation water from unconventional natural gas extraction in coal and shale: International Journal of Coal Geology, v. 126, p. 20-31, https://doi.org/10.1016/j.coal.2014.01.003.

Osborn, S.G., and McIntosh, J.C., 2010, Chemical and isotopic tracers of the contribution of microbial gas in Devonian organic-rich shales and reservoir sandstones, northern Appalachian Basin: Applied Geochemistry, v. 25, no. 3, p. 456-471, https://doi.org/10.1016/j.apgeochem.2010.01.001.

Plummer, N.L., and Sprinkle, C.L., 2001, Radiocarbon dating of dissolved inorganic carbon in groundwater from confined parts of the Upper Floridan aquifer, Florida, USA: Hydrogeology Journal, v. 9, no. 2, p. 127-150, https://doi.org/10.1007/s100400000121.

Roy, N., Molson, J., Lemieux, J.-M., Van Stempvoort, D., and Nowamooz, A., 2016, Three-dimensional numerical simulations of methane gas migration from decommissioned hydrocarbon production wells into shallow aquifers: Water Resources Research, v. 52, no. 7, p. 5598-5618, https://doi.org/10.1002/2016WR018686.

Spangler, L.E., Naftz, D.L., and Peterman, Z.E., 1996, Hydrology, chemical quality, and characterization of salinity in the Navajo aquifer in and near the Greater Aneth Oil Field, San Juan County, Utah: U.S. Geological Survey Water-Resources Investigations Report 96-4155, 90 p.

Steiger, J.I., 2007, Effects of saline-wastewater injection on water quality in the Altamont-Bluebell oil and gas field, Duchesne County, Utah, 1990-2005: U.S. Geological Survey Scientific Investigations Report 2007-5192, 29 p., https://doi.org/10.3133/sir20075192.

Tamers, M.A., 1975, Validity of radiocarbon dates on ground water: Geophysical Surveys, v. 2, no. 2, p. 217-239, https://doi.org/10.1007/BF01447909.

U.S. Environmental Protection Agency, 2018, Drinking water contaminants-Standards and regulations: U.S. Environmental Protection Agency web page, accessed April 10, 2018, at https://www.epa.gov/dwstandardsregulations. 
U.S. Geological Survey, variously dated, U.S. Geological Survey National Field Manual for the collection of waterquality data: U.S. Geological Survey Techniques of Water-Resources Investigations, book 9, chaps. A1-A10, http://pubs.water.usgs.gov/twri9A.

Utah Department of Natural Resources, Division of Oil, Gas and Mining, 2017, Oil and gas datasets: Utah Automated Geographic Reference Center web page, accessed March 19, 2019, at https://gis.utah.gov/data/energy/oil-gas/.

Vengosh, A., Jackson, R.B., Warner, N., Darrah, T.H., and Kondash, A., 2014, A critical review of the risks to water resources from unconventional shale gas development and hydraulic fracturing in the United States: Environmental Science \& Technology, v. 48, no. 15, p. 8334-8348, https://doi.org/10.1021/es405118y.

Warner, N.R., Jackson, R.B., Darrah, T.H., Osborn, S.G., Down, A., Zhao, K., White, A., and Vengosh, A., 2012, Geochemical evidence for possible natural migration of Marcellus Formation brine to shallow aquifers in Pennsylvania: Proceedings of the National Academy of Sciences, v. 109, no. 30, p. 11961-11966, https://doi.org/10.1073/pnas.1121181109.

Waterisotopes Database 2018, The online isotopes in precipitation calculator (ver. 3.1): University of Utah, web page accessed April 16, 2018, at http://www.waterisotopes.org.

Werner, A.K., Vink, S., Watt, K., and Jagals, P., 2015, Environmental health impacts of unconventional natural gas development-A review of the current strength of evidence: Science of the Total Environment, v. 505, p. 1127-1141, https://doi.org/10.1016/j.scitotenv.2014.10.084.

Whitfield, M.S., Thordarson, W., Oatfield, W.J., Zimmerman, E.A., and Rueger, B.F., 1983, Regional hydrology of the Blanding-Durango area, southern Paradox Basin, Utah and Colorado: U.S. Geological Survey WaterResources Investigations Report 83-4218, 88 p. 
For more information concerning the research in this report, contact the Director, Utah Water Science Center

U.S. Geological Survey

2329 West Orton Circle

Salt Lake City, Utah 84119-2047

801-908-5000

https://ut.water.usgs.gov 


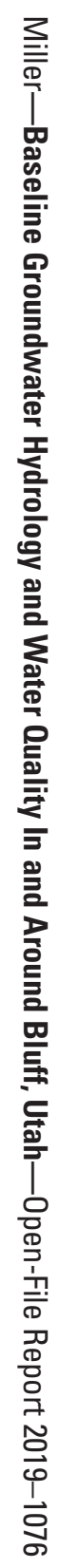

